\title{
Molecular Aspects of Volatile Anesthetic-Induced Organ Protection and Its Potential in Kidney Transplantation
}

\author{
Gertrude J. Nieuwenhuijs-Moeke ${ }^{1, * \mathbb{D}}$, Dirk J. Bosch ${ }^{1}$ and Henri G.D. Leuvenink ${ }^{2}$ \\ 1 Department of Anesthesiology, University Medical Centre Groningen, University of Groningen, Hanzeplein 1, \\ 9713 GZ Groningen, The Netherlands; d.j.bosch@umcg.nl \\ 2 Department of Surgery, University Medical Centre Groningen, University of Groningen, Hanzeplein 1, \\ 9713 GZ Groningen, The Netherlands; h.g.d.leuvenink@umcg.nl \\ * Correspondence: g.j.nieuwenhuijs-moeke@umcg.nl; Tel.: +31-631623075
}

Citation: Nieuwenhuijs-Moeke, G.J.;

Bosch, D.J.; Leuvenink, H.G.D.

Molecular Aspects of Volatile

Anesthetic-Induced Organ Protection and Its Potential in Kidney

Transplantation. Int. J. Mol. Sci. 2021,

22, 2727. https://doi.org/10.3390/ ijms22052727

Academic Editor: Raphael Thuillier

Received: 2 February 2021

Accepted: 3 March 2021

Published: 8 March 2021

Publisher's Note: MDPI stays neutral with regard to jurisdictional claims in published maps and institutional affiliations.

Copyright: (c) 2021 by the authors. Licensee MDPI, Basel, Switzerland. This article is an open access article distributed under the terms and conditions of the Creative Commons Attribution (CC BY) license (https:/ / creativecommons.org/licenses/by/ $4.0 /)$.

\begin{abstract}
Ischemia reperfusion injury (IRI) is inevitable in kidney transplantation and negatively impacts graft and patient outcome. Reperfusion takes place in the recipient and most of the injury following ischemia and reperfusion occurs during this reperfusion phase; therefore, the intra-operative period seems an attractive window of opportunity to modulate IRI and improve short- and potentially long-term graft outcome. Commonly used volatile anesthetics such as sevoflurane and isoflurane have been shown to interfere with many of the pathophysiological processes involved in the injurious cascade of IRI. Therefore, volatile anesthetic (VA) agents might be the preferred anesthetics used during the transplantation procedure. This review highlights the molecular and cellular protective points of engagement of VA shown in in vitro studies and in vivo animal experiments, and the potential translation of these results to the clinical setting of kidney transplantation.
\end{abstract}

Keywords: ischemia reperfusion injury; kidney transplantation; anesthetic conditioning; organ protection; volatile anesthetics; anesthesiology

\section{Introduction}

During the process of kidney donation and transplantation a number of potentially harmful processes will inevitably occur, which affect the viability of the graft. The donor organ is, by definition, exposed to a period of ischemia which lasts until the kidney is reconnected to the circulation of the recipient. In the case of deceased kidney donation, additional injury occurs even before graft removal. The pro-inflammatory and pro-coagulatory systemic and local renal response to brain death in the case of deceased brain dead (DBD) donors and the variable and often extended period of warm ischemia and hypoxia in the case of deceased circulatory death (DCD) donors, result in further impairments, reducing post-transplant graft function and survival. These combined effects on the graft-to-be result in a cascade of renal damage that will reveal itself at the time of transplantation when the donor kidney is reperfused in the recipient and is called ischemia reperfusion injury (IRI). Typically, IRI manifests as immediate non-function of the graft with the need for dialysis treatment until the graft recovers from the insult and starts to function. This "secondary" recovery is called delayed graft function (DGF). In cases where the injury has been too extensive to repair the transplanted kidney and it will never recover nor regain function, this is called primary non function (PNF). DGF and PNF are clinically relevant problems. Both are associated with increased morbidity, patient anxiety, prolonged hospitalization, and additional diagnostic procedures and costs. Furthermore, DGF is associated with acute rejection (AR), and the combination of DGF and AR reduces graft and patient survival $[1,2]$.

IRI consists of a complex pathophysiology in which several molecular pathways and signaling cascades are involved [3]. It is amongst others associated with dysfunctioning of the mitochondrial respiratory chain and uncontrolled formation of reactive oxygen species (ROS) during reperfusion, leading to opening of the mitochondrial permeability 
transition pores (mPTP) and release of danger-associated molecular patterns (DAMPs) into the intra- and extracellular space [4,5]. From here, several injury cascades are implicated, including the activation of cell death programs such as apoptosis and (regulated) necrosis and endothelial dysfunction with loss of the glycocalyx and transmigration of leucocytes into the interstitial space. The DAMPs released upon reperfusion will further harm the graft by binding to pattern recognition receptors (PRR) such as toll-like receptors (TLR) and receptors of the complement system, leading to activation of the innate and subsequently the adaptive immune system [3]. This will increase the immunogenicity of the graft, favoring $\mathrm{T}$ cell and antibody mediated rejection (ABMR) and the initiation or progression of interstitial fibrosis associated with chronic graft dysfunction. In addition, protective pathways in cells are activated upon IRI by means of activation of transcription factors such as hypoxia inducible factors (HIFs) involved in the regulation of genes associated with the metabolic cell cycle, angiogenesis, and cell survival [6].

Conditioning is a broad term generally used to describe strategies inducing biochemical changes that attenuate IRI. Dependent on timing of application of the strategy, it is referred to as pre- (before ischemia), per- (during ischemia), or post- (directly upon reperfusion) conditioning. It was first described in 1986 by Murry and colleagues [7]. They reported that subjecting the heart to four brief ischemic episodes, followed by reperfusion, preceding a prolonged ischemic insult, reduced myocardial infarct size by $75 \%$ in a canine model [7]. This phenomenon is called ischemic preconditioning (IPC). Subsequently, it was found that ischemic conditioning (IC) upon reperfusion of the heart (ischemic postconditioning, IPostC) or applied to a remote tissue or organ (remote ischemic conditioning, RIC) had a similar protective effect on the myocardium $[8,9]$. Following the heart, $(\mathrm{R}) \mathrm{IC}$ was also described for various other organs including the liver, brain, lungs, and kidney [10-13]. In addition, several non-ischemic stimuli (such as hyperthermia or transient pacing) and pharmacological substances (such as erythropoietin and nicorandil) were also found to confer cellular tolerance to a major ischemic period by underlying mechanisms similar to those mediating IC [14-21]. This is also the case for some of the generally used anesthetics agents, which is called anesthetic conditioning (AC). AC is particularly attributed to volatile anesthetic (VA) agents, such as sevoflurane, isoflurane and desflurane, and to a lesser extent to the intravenous anesthetic agent propofol. Next to this, VA affect various cells of the immune system, either by direct interaction of the drug with the cell or indirectly, by altering environmental conditions; hence IRI, of which many of these effects seem favorable during (kidney) transplantation. Therefore, the use of VA during the donation, transplantation, and even the preservation period, could be an attractive way to reduce injury and improve graft function. This review highlights the molecular and cellular protective points of engagement of VA shown in in vitro studies and in vivo animal experiments, and the potential translation of these results to the clinical setting of kidney transplantation.

\section{Anesthetic Conditioning and Organ Protection with Volatile Anesthetic Agents}

Anesthetic agents have pleiotropic effects, meaning that there are effects other than inducing anesthesia and analgesia, which affect many cells and systems in our body. This was already reported in the beginning of the 20th century. In 1911, Gaylord and Simpson showed that breast cancer cells grew more rapidly in mice when exposed to ether or chloroform [22]. A few years later, in 1916, Graham reported that leucocytes exposed to ether showed impaired phagocytosis of streptococci [23]. After these early findings, it was quiet in this area of research for a long period of time, but in the past few decades there has been a growing interest in the effects of our generally used anesthetic and analgesic agents on various organs, the immune system, and phenomena such as IRI. Experiments on pulmonary epithelial and endothelial cells suggest that the trifluoronated carbon groups, which are part of all modern VA, are responsible for the anti-inflammatory and immunomodulatory effects [24]. 
The first paper describing the advantageous effects of VA on IRI dates back to 1976, in which Bland and Lowenstein reported the protective properties of halothane on the myocardium in an ischemia and reperfusion (I/R) model of a canine heart [25]. In 1988, Warltier et al. showed that the recovery of cardiac function after exposing the myocardium to a brief period of ischemia was enhanced by isoflurane. Dogs anesthetized with isoflurane regained full contractile performance within two hours after reperfusion compared to control animals, which after five hours regained only $50 \%$ of their baseline contractile performance [26]. Since then, numerous animal studies and clinical trials have been published reporting the cardioprotective properties of VA against IRI and elucidating mechanistic pathways. Several meta-analyses have been performed comparing the use of VA versus propofol on cardiac and patient outcome in cardiac surgery, with results ranging from no or minor difference (e.g., lower cardiac-troponin-1,cTn1) to a reduction in cardiac complications, inotropic requirements, duration of mechanical ventilation, and mortality in the advantages of VA [27-29]. Modes of application of the VA in these studies ranged from specific pre- or postconditioning protocols to administration of the VA during the entire surgical procedure. The most recent and largest meta-analysis, performed by Bonnani et al. including 42 trials and 8197 patients, however, showed that VA are superior to propofol on long term mortality and postoperative morbidity [30]. In their analysis, the use of VA in patients undergoing cardiac surgery with the use of cardiac pulmonary bypass was associated with a lower one-year mortality, myocardial infarction, lower cTnT release, less need for inotropic support, shorter extubation time, and higher cardiac index/cardiac output compared to the use of propofol, indicating a myocardial protective effect of VA in this setting [30].

In addition to the heart, protective effects of VA are also described for other organs such as the lungs, liver, brain, and kidney, both in vitro and in vivo in different animal species [31-41]. Regarding the kidney, evidence of protection is either indirect or restricted to animal work. In rats, Lee et al. showed that clinically relevant concentrations (1 minimal alveolar concentration, MAC) of VA (sevoflurane and isoflurane) administered both during and after renal ischemia conferred profound protection against renal IRI, resulting in dramatically lower plasma creatinin levels and reduced renal necrosis $24-72 \mathrm{~h}$ after injury, compared with rats that received the intravenous agents pentobarbital or ketamine [42]. In mice subjected to renal I/R, anesthesia with isoflurane led to reduced infiltration of neutrophils, macrophages and lymphocytes post-reperfusion compared to mice anesthetized with pentobarbital [43]. Ko et al. studied the impact of choice of anesthetic agent on a variety of renal and hepatic function markers in patients undergoing hemi-hepatectomy [44]. Typically, during this procedure, very conservative fluid administration regimes are used. While this may achieve the aim of limiting intraoperative blood loss, it also jeopardizes renal function if significant renal hypoperfusion and ischemia occurs. In this study, patients who received desflurane had significantly better creatinine and glomerular filtration rate (GFR) values on the first day after surgery than patients anesthetized with propofol.

Mechanistically, protection against IRI with the use of VA most likely is not conferred by the activation of one single pathway. VA have been shown to interact with many of pathophysiological processes involved in IRI. These points of engagement are outlined below and summarized in Figure 1. 


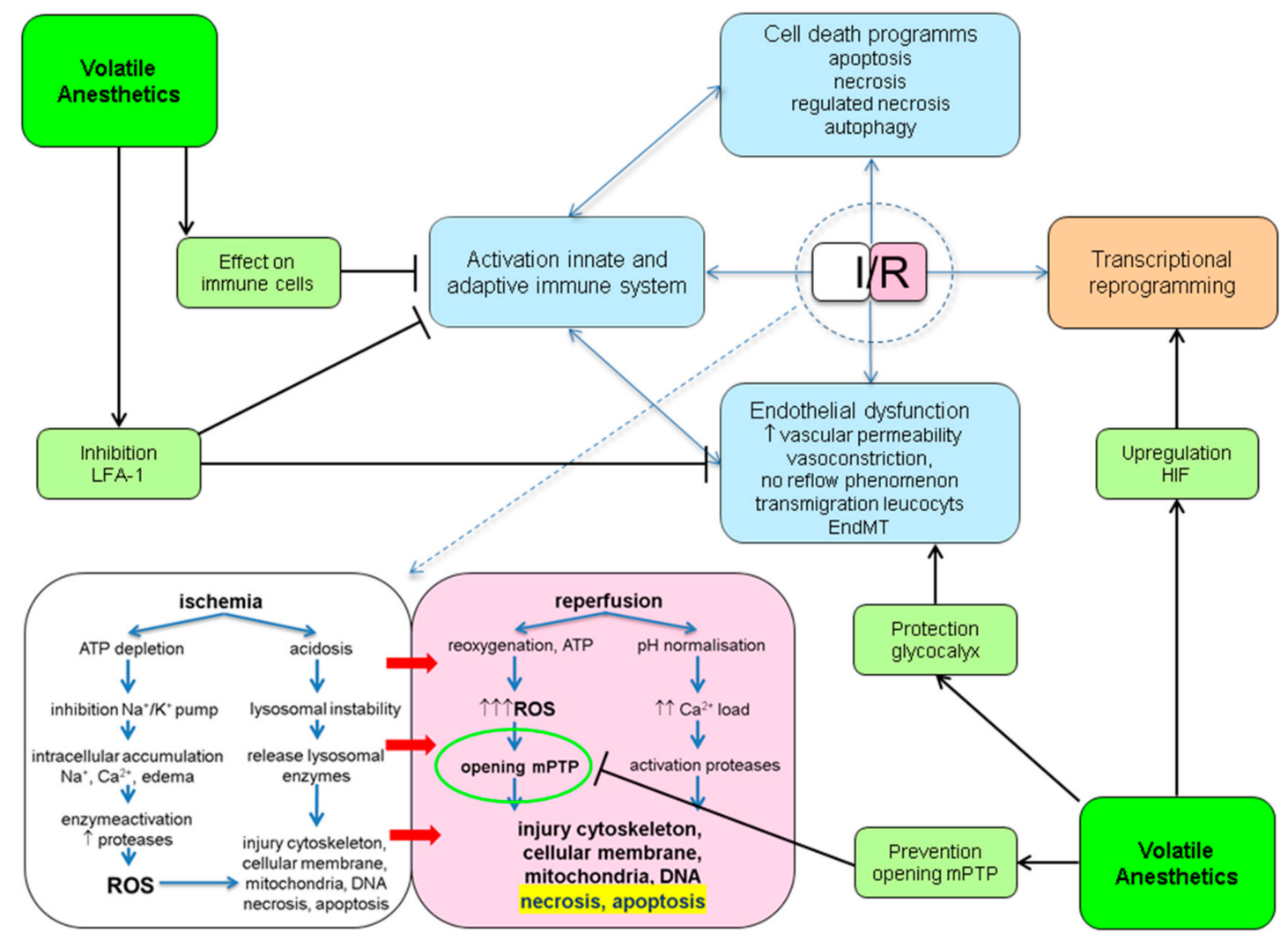

Figure 1. Potential protective points of engagement of volatile anesthetics (VA) in ischemia reperfusion injury (IRI). ATP: adenosine triphosphate; EndMT: endothelial to mesenchymal transition; HIF: hypoxic inducible factor; I/R: ischemia/reperfusion; LFA-1: lymphocyte function antigen-1; mPTP: mitochondrial permeability transition pore; ROS: reactive oxygen species.

\subsection{Prevention of Opening of the $M P T P$}

Induction and opening of mPTP is an important early step in the cascade of injurious events in IRI. Opening of the MPTP will lead to the release of substances such as cytochrome C, succinate and mitochondrial DNA in the intracellular space which are able to activate cell death programs such as apotosis or (regulated) necrosis. In addition, the substances released may act as DAMPs, activating the innate immune system by binding to PRR [5]. Prevention of opening of MPTP has been shown to be an effective strategy to reduce IRI [45]. Administration of VA in the early phase of reperfusion is able to inhibit mPTP opening, most likely through multiple pathways, as displayed in Figure 2. VA are likely to reduce the activity of complex III in the mitochondrial respiratory chain, which results in an increase in superoxide (an ROS) formation. The superoxide formed reacts with nitric oxide, resulting in the formation of peroxynitrite, which itself reduces electron transport at complex I of the respiratory chain, leading to more superoxide formation [46-49]. The amounts of ROS formed in this process, however, are significantly lower than the harmful concentrations formed in the case of prolonged I/R.

In cytosol, superoxide acts as a second messenger and is able to induce translocation of protein kinase $\mathrm{C}-\varepsilon(\mathrm{PKC}-\varepsilon)$ to the mitochondrial membrane [50]. Phosphorylation of PKC $-\varepsilon$ causes opening of the $\mathrm{K}^{+}$-adenosine triphosphate (ATP)ase channels, resulting in an influx of $\mathrm{K}^{+}$into the mitochondria, reducing the inner membrane potential. These reductions in membrane potentials have been shown to prevent mPTP production [51]. Additionally, superoxide is able to activate the reperfusion injury salvage kinase (RISK) pathway, in which the inhibition of glycogen synthase kinase 3 beta (GSK-3 $\beta$ ) and formation of nitric oxide (NO) via endothelial nitric oxide synthase (eNOS) will lead to the prevention of mPTP opening or closing of mPTP $[52,53]$. The link between VA-induced activation of the RISK pathway and prevention of mPTP opening has been well established [54-61]. In 
contrast, the contribution of the survivor activating factor enhancement (SAFE) pathway in the VA-induced prevention of MPTP opening is less clear [62]. Superoxide may activate the SAFE pathway in which increases in anti-apoptotic B cell lymphoma 2 (Bcl- 2) activity leads to mPTP closing [63-65].

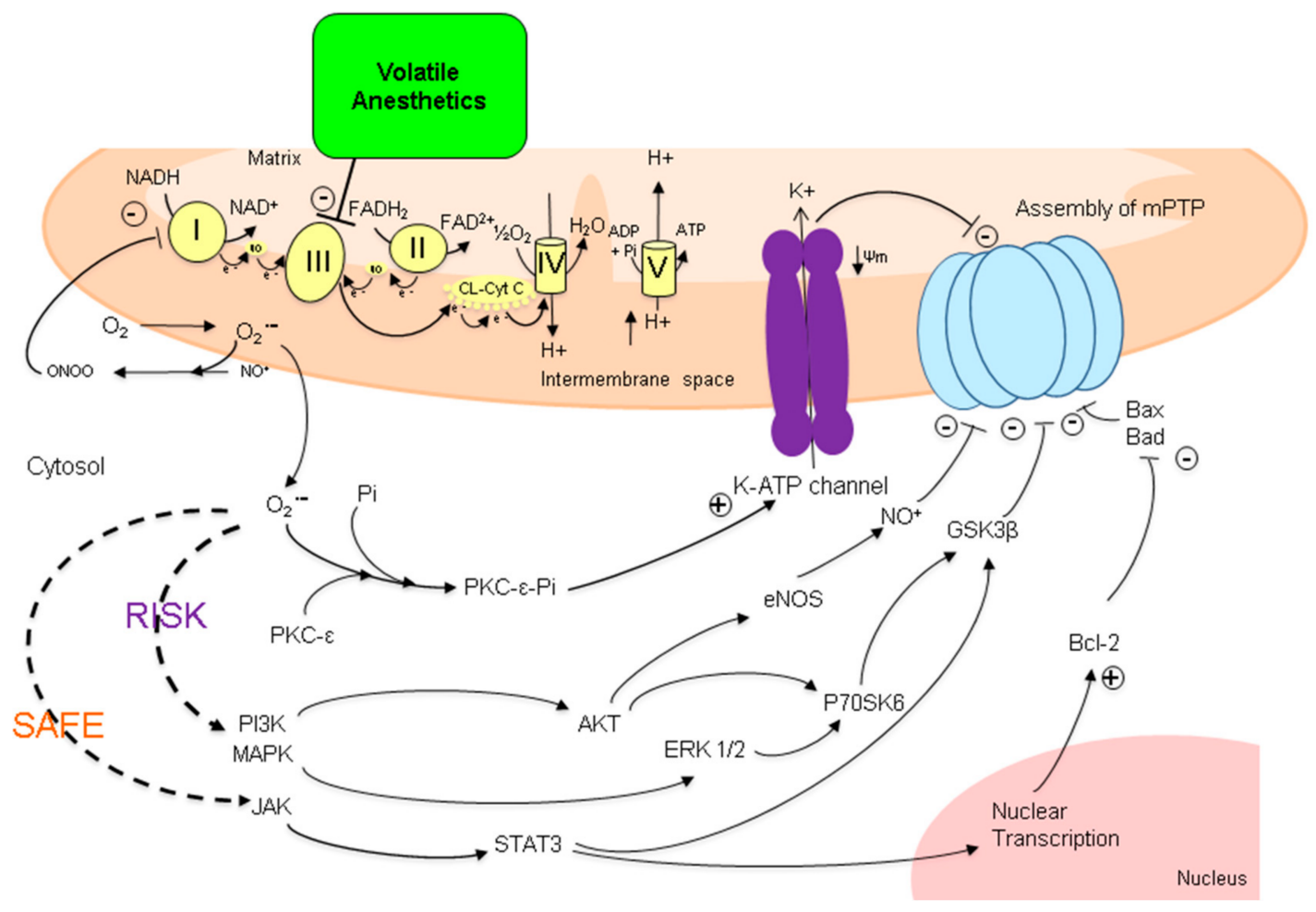

Figure 2. Proposed effects of volatile anesthetics on the level of mitochondria. VA are likely to reduce complex III activity in the mitochondrial respiratory chain, resulting in an increase in superoxide (an ROS) formation. Superoxide then may react with nitric oxide, resulting in the formation of peroxynitrite, which itself reduces electron transport at complex I leading to more superoxide formation. From here, several pathways can be induced, ultimately resulting in reduced formation of mPTP (via PKC) or the prevention of opening of MPTP (via RISK or SAFE pathways). NAD: nicotinamide-adeninedinucleotide; FAD: flavin-adenine-dinucleotide; CL-Cyt C: cytochrome C oxidase; PKC- $\varepsilon$ : protein kinase C- $\varepsilon$; Pi: phosphate; Im: membrane potential; mPTP: mitochondrial permeability transition pore; PI3K: phosphoinositol 3 kinase; MAPK: mitogen activated kinse; JAK: Janus kinase; AKT: protein kinase B; eNOS: endothelial nitric oxide synthase; NO: nitric oxide; ERK1/2: extracellular signal-regulated kinases1/2; P70SK6: ribosomal protein S6 kinase beta-1; GSK3 $\beta$ : glycogen synthase kinase 3 beta; Bcl-2: B cell lymphoma 2; Bax: bcl-2-like protein 4; Bad: BCL2 associated agonist of cell death; RISK pathway: reperfusion injury salvage kinase; SAFE pathway: survivor activating factor enhancement pathway.

In primary cultured rat cardiocytes exposed to three hours of hypoxia followed by two hours of reoxygenation, $\mathrm{Wu}$ et al. showed that treatment with isoflurane during the hypoxic period significantly attenuated hypoxia/reoxygenation-induced apoptosis. In their experiment, isoflurane pretreatment prevented excessive ROS formation upon reoxygenation, attenuated $\mathrm{mPTP}$ opening, and as a result inhibited the activation of caspase 3 [66]. In a very elegant experiment, Pravdic et al. investigated the in vivo effect of isoflurane post-conditioning on cardiac mitochondria in rats exposed to cardiac I/R [67]. They showed that isoflurane protected against $\mathrm{mPTP}$ opening, slowed mitochondria respiration, and depolarized mitochondria. In addition, they studied the effect of isoflurane on isolated cardiomyocytes and isolated mitochondria subjected to I/R. Cells treated with isoflurane during reoxygenation showed attenuated intracellular $\mathrm{Ca}^{2+}$ accumulation, maintained a lower $\mathrm{pH}$, and preserved the mitochondrial membrane potential during reperfusion. In mitochondria, a preserved ATP production and respiration was observed. A mildly acidotic $\mathrm{pH}$ at the time of reperfusion has been shown to be crucial for protection against 
IRI [68,69]. It has been suggested that the delayed opening of mPTP at lower $\mathrm{pH}$ values generates time for protective signaling pathways to be activated [68,69]. Pravdic et al. showed that the preserved acidotic mitochondrial $\mathrm{pH}$ after reperfusion may not be related to anaerobic metabolism during reperfusion, because isoflurane treatment also decreased mitochondrial $\mathrm{pH}$ under normoxemic conditions [67]. They suggest a direct effect of isoflurane on mitochondrial bioenergetics by mild inhibition of complex I, resulting in reduced $\mathrm{H}^{+}$pumping out of the mitochondria or increased $\mathrm{H}^{+}$influx due to mitochondrial uncoupling [70-72]. The study of Pravdic et al. demonstrated that post-conditioning with VA produces a significant protection of mitochondria in cardiomyocytes; whether this is also the case in renal tubular cells is unclear.

\subsection{Protective Effects on the Glycocalyx}

VA have been shown to protect the glycocalyx and to reduce endothelial injury in IRI. The glycocalyx, located on the luminal side of the vascular endothelial cells, represents a 0.1-11.0 $\mu \mathrm{m}$ layer (depending on measurement technique, localization, and species), consisting of a dynamic network of membrane-bound proteoglycans and glycoproteins [73-77]. The proteoglycans have a protein core, consisting of transmembrane syndecans, membraneanchored glypicans, or secreted core proteins such as versicans, biglycans, and a various number of negatively charged glycosaminoglycan (GAG) side chains. Of these GAGs, $50-90 \%$ consist of heparan sulfate, and the remaining part of hyaluronic acid, chondroitin, dermatan and keratan sulphate [78]. Hyaluronic acid is the only GAG not covalently attached to a core protein; instead, it interacts with the endothelium by attaching to the transmembrane receptor cluster of differentiation (CD)44 [79]. It is much longer than the other GAGs and weaves through the glycocalyx [80]. Within this network of proteoglycans lie several types of glycoproteins, such as von Willebrand factor (vWF) and adhesion molecules. These adhesion molecules consist of selectins (E/Pselectin), integrins and immunoglobulins (intercellular adhesion molecule (ICAM)-1, ICAM-2, vascular cell adhesion molecule 1 (VCAM-1), platelet endothelial cell adhesion molecule 1 (PECAM-1)), which are ligands for the integrins on leucocytes and platelets, facilitating adhesion to the endothelium and transmigration to the interstitial space. Injury to the glycocalyx in the case of IRI leads to a disrupted endothelial barrier with platelet aggregation, hypercoagulabilty, inflammation, and increased vascular permeability [81]. In an isolated guinea pig heart model, hearts were subjected to $20 \mathrm{~min}$ of ischemia with or without $1 \mathrm{MAC}$ sevoflurane administration $15 \mathrm{~min}$ before ischemia and/or during reperfusion. In the non-treated hearts, IRI led to a 70\% increase in fluid extravasation and reduced coronary flow. In addition, increased levels of syndecan-1 and heparan sulphate were measured, indicating degradation of the glycocalyx. Sevoflurane treatment, pre- and post-conditioning, attenuated these changes and protected the glycocalyx from shedding [82]. The authors attribute this effect to lysosomal membrane stabilization by sevoflurane, with a consequent lower release of cathepsin B. This lysosomal protease is associated with degradation of the extracellular matrix and is released upon injury. Lower cathepsin B levels were measured in the treated groups [82]. The same research group showed that $1 \mathrm{MAC}$ sevoflurane preconditioning led to reduced (to near baseline levels) cellular adhesion of infused human leukocytes and platelets in an isolated guinea pig heart model subjected to $20 \mathrm{~min}$ of warm ischemia and $10 \mathrm{~min}$ of reperfusion. In the non-treated group, 39\% of the infused leukocytes and $25 \%$ of the platelets adhered to the endothelium, respectively. In the treated group, this was $22 \%$ and $12 \%$, respectively. Again, the non-treated group showed increased levels of syndecan-1 and heparan sulfate. Electron microscopy showed a preserved integrity of the glycocalyx in the treated group [83]. In addition, in an isolated guinea pig model with hearts perfused with a modified Krebs-Henseleit buffer, perfused with a oxygenated pulsatile flow at $70 \mathrm{~cm} \mathrm{H}_{2} \mathrm{O}$ and subjected to $20 \mathrm{~min}$ of warm ischemia followed by $40 \mathrm{~min}$ of reperfusion, Chen et al. showed that an addition of sevoflurane at $2 \%$ (1 MAC) to the gas mixture before ischemia and during reperfusion strongly inhibited the shedding of hyaluronic acid during the entire period, even prior to ischemia [84]. Treatment with 
sevoflurane completely prevented the increase in coronary leak seen in the non-treated group. Electron microscopy revealed a distinct glycocalyx present in the treated group, whereas in the non-treated group the glycocalyx could not be visualized. Global oxidative stress measured with the purine/uric acid ratio did not differ between groups. Next to this, there was no difference between groups in lactate washout, indicating that the ischemic impact on the hearts was similar in both groups and sevoflurane treatment seems not to influence this. Local effects at the vessel wall, however, cannot be excluded. In an in vivo pig model subjected to $90 \mathrm{~min}$ of ischemia induced by balloon insufflation in the thoracic aorta, followed by $120 \mathrm{~min}$ of reperfusion, Annecke et al. compared the effect of sevoflurane anesthesia to a propofol anesthesia at clinically relevant concentrations on unmeasured anions (represented by the strong ion gap (SIG), predictive of negative outcome) and shedding of heparan sulphate. In the propofol-treated animals, SIG significantly increased after reperfusion, which was not the case in sevoflurane-treated animals. In both groups, levels of heparan sulphate increased after reperfusion. In the sevoflurane animals, this increase stabilized after $120 \mathrm{~min}$ of reperfusion, whereas in the propofol-treated animals shedding of HS continued to rise, suggesting a superior role of sevoflurane over propofol in protection of the endothelial glycocalyx [85]. Modern organ preservation of kidney grafts has shifted from cold storage to hypothermic machine perfusion and has now entered an era of normothermic oxygenated machine perfusion. Based on the obtained knowledge described above, the addition of a VA to the perfusate might be a potential therapeutic strategy to protect the integrity of the glycocalyx and reduce exposure of endothelial-bound proteins such as vWF and adhesion molecules.

\subsection{Upregulation of Hypoxia Inducible Factors (HIFs)}

HIFs are heterodimeric transcription factors protecting the cell against IRI by the regulation of genes involved in metabolic cell cycle, facilitating cellular adaptation to low oxygen conditions. Under normal conditions, the amino acid proline on the $\alpha$ subunit is rapidly hydroxylated by oxygen-sensing prolylhydroxylases (PHD), inducing conformational changes enabling von Hippel-Lindau tumor suppressor protein (pVHL) to bind with the $\alpha$-subunit, leading to degradation of the complex. Ischemia/hypoxia inhibits the PHD, which enables nuclear translocation of the $\alpha$-subunit, binding of the $\alpha$-subunit to the $\beta$-subunit, and the formation of HIF. In the nucleus, HIF will bind with the hypoxia response promotor element (HRE) and the transcription of various protective genes, such as adenosine receptors, VGEF and erythropoietin. There are two types of $\alpha$-subunits, HIF- $1 \alpha$ and HIF- $2 \alpha$, which have common but also specific target genes. In the kidney, HIF- $1 \alpha$ is predominantly located in glomerular and tubular cells, whereas HIF- $2 \alpha$ can be found in glomerular cells, endothelial cells, and fibroblasts [86-88]. Several studies suggest a protective role of HIFs during renal IRI. Oda et al. showed that increased expression of HIF- $1 \alpha$ after reperfusion was associated with improved graft outcome in deceased donor kidney transplant recipients [89]. Kojima et al. showed, in a renal I/R mouse model, that HIF- $2 \alpha^{-/-}$mice showed increased renal injury compared to HIF- $2 \alpha^{+/+}$mice. Along with the direct protective effects of HIFs by transcription of protective genes, increasing evidence suggests the role of HIF activation in the modulation of other protective signaling pathways [90].

The ability of VA to upregulate HIF- $1 \alpha$ and HIF- $2 \alpha$ is being considered as one of the underlying mechanisms of AC. In an isolated I/R rat heart model, Yang and colleagues showed that $15 \mathrm{~min}$ of sevoflurane exposure upon reperfusion resulted in an upregulation of HIF-1 $\alpha$. Sevoflurane-treated hearts showed improved mitochondrial function and structure and improved cardiac function compared to non-treated hearts [91]. These protective effects were abolished if the hearts were treated with 2-methoxyestradiol, an HIF- $1 \alpha$ inhibitor [91]. In a renal I/R model, wild type mice pretreated with sevoflurane showed significantly lower blood urea nitrogen (BUN) and creatinine levels and higher HIF- $2 \alpha$ expression compared to wild type mice without sevoflurane pretreatment and HIF- $2 \alpha^{(-/-)}$knock out mice pretreated with sevoflurane [92]. 
Zhao and colleagues report interesting findings of the influence of xenon (Xe), a potent anesthetic gas, on HIF- $1 \alpha$ upregulation in an in vitro model of human proximal tubular cells (PTC) and an in vivo rat transplant model [93]. Human PTCs were subjected to a $24 \mathrm{~h}$ period of hypoxic cold preservation and pre- ( $24 \mathrm{~h}$ before hypoxia) or post-conditioning (upon reperfusion) by a $2 \mathrm{~h}$ exposure of a gas mixture containing $70 \% \mathrm{Xe}-5 \% \mathrm{CO}_{2}-25 \% \mathrm{O}_{2}$. Both groups showed upregulation of HIF- $1 \alpha$, VGEF and Bcl-2 compared to non-treated PTCs. Furthermore, the Xe-treated cells showed an improved cytoskeleton, significantly lower translocation of high mobility group box-1 (HMGB-1) from the nucleus into the cytosol, and less activation of TLR4. These results were abolished when the gene silencer HIF- $1 \alpha$ siRNA was administered. In their iso- and allograft transplant model, rats were exposed to a $70 \% \mathrm{Xe}-30 \% \mathrm{O}_{2}$ or $70 \% \mathrm{~N}_{2} \mathrm{O}-30 \% \mathrm{O}_{2}$ mixture $24 \mathrm{~h}$ before organ retrieval (donor) or directly upon reperfusion (recipient). Kidneys underwent cold storage at $4{ }^{\circ} \mathrm{C}$ for 16(allografts)-24(isografts) $\mathrm{h}$. Both pre- and post-conditioning resulted in reduced nuclear translocation of HMGB-1 and TLR4 activity as well as lower serum levels of HMGB-1. Xe treatment led to decreased NF- $\mathrm{KB}$ and caspase 3 expression, and serum levels Il- $1 \beta$, tumor necrosis factor $\alpha$ (TNF- $\alpha$ ), IL-6 were reduced. Again, the addition of siRNA HIF- $1 \alpha$ abolished the renoprotective effects. Graft survival was significantly prolonged in the Xe-treated groups in both transplant models, and Xe-treated allografts showed reduced CD3+ T cell infiltration at day 20. Taken together, the HIF-1 $\alpha$ upregulation could have induced nuclear and cytoskeletal stability leading to decreased HMGB-1/TLR4 signaling, resulting in lower expression of NF- $\mathrm{KB}$ and caspase activation. The authors suggested the Xe induced phosphoinositol 3 kinase (PI3K)- protein kinase B (Akt)- mammalian target of rapamycin (mTOR) pathway to be responsible for the upregulation of HIF- $1 \alpha$ but could not confirm this [93]. In several studies in myocardial or cerebral cells, however, the upregulations of HIF- $1 \alpha$ by sevoflurane and isoflurane via the PI3K-Akt-mTOR pathway have been shown [94,95]. Propofol, on the other hand, has been shown to abolish HIF-1 $\alpha$ upregulation by isoflurane or inhibit HIF- $1 \alpha$ production itself $[79,96,97]$.

\subsection{Effect on Renal Tubular Cells and Sphingosine-1-Phosphate Signaling Pathway}

Lee et al. performed extensive research on the impact of VA on I/R injured renal tubular cells in several in vitro and animal experiments (Figure 3). They showed that VA exposure induces translocation of phosphatidylserine (PS) to the outer leaflet of the plasma membrane [98]. This externalization of PS inflicts a release of transforming growth factor- $\beta$ (TGF- $\beta$ ) in neighboring cells via the ligation of PS receptors. Externalization of PS is a strong apoptotic signal for macrophages to engulf these cells. In addition, PS externalization entails an increase in caveolae formation in the cell membrane with sequestration of key signaling proteins such as TGF- $\beta$ receptors, extracellular regulated kinase (ERK), sphingosine kinase 1 (SK-1), and sphingosine-1-phosphate [40,99-101]. Binding of TGF- $\beta$ to the TGF- $\beta$ receptor results in increased expression of CD-73 via the nuclear translocation of transcription factor mothers against decapentaplegic homolog 3 (SMAD-3). This increased CD-73 expression enhances the formation of adenosine, a well-known potent anti-inflammatory mediator. Adenosine induces protection upon reperfusion by activating, amongst others, the RISK and the SAFE pathways [102-104]. Lee et al. showed that, in renal tubular cells, activation of adenosine receptor (A1AR) by adenosine results in sphingosine kinase (SK-1) upregulation. This occurs directly via hypoxic inducible factor $1 \alpha$ (HIF-1 $\alpha$ ) signaling, or indirectly via increased IL-11 synthesis through the activation of the ERK/mitogen-activated protein kinase (ERK/MAPK) signaling pathway [105-107]. SK-1 itself promotes sphinogosine-1-phosphate (S1P) synthesis, which targets the S1P-receptor (S1PR), a G protein-coupled receptor which is sequestered in the caveolae. S1P-S1PR signaling is associated with cell survival and cell growth via the RISK and SAFE pathways $[105,108-113]$. Lee et al. showed that, in renal cells, S1P-S1PR signaling plays an important role in VA-induced protection. Blockade of the S1PR with a selective antagonist abolished the protective effect of isoflurane in renal tubular and endothelial cells, as was the case for SK-1 inhibitors [114]. The role of S1P signaling in renal IRI and transplantation 
is increasingly recognized. In mice subjected to renal $I / R$, treatment with the selective S1PR agonist FTY720 attenuated IRI [115]. In a renal transplant model, rats treated with FTY720 reduced apoptosis and increased the proliferation of renal tubular cells [116].

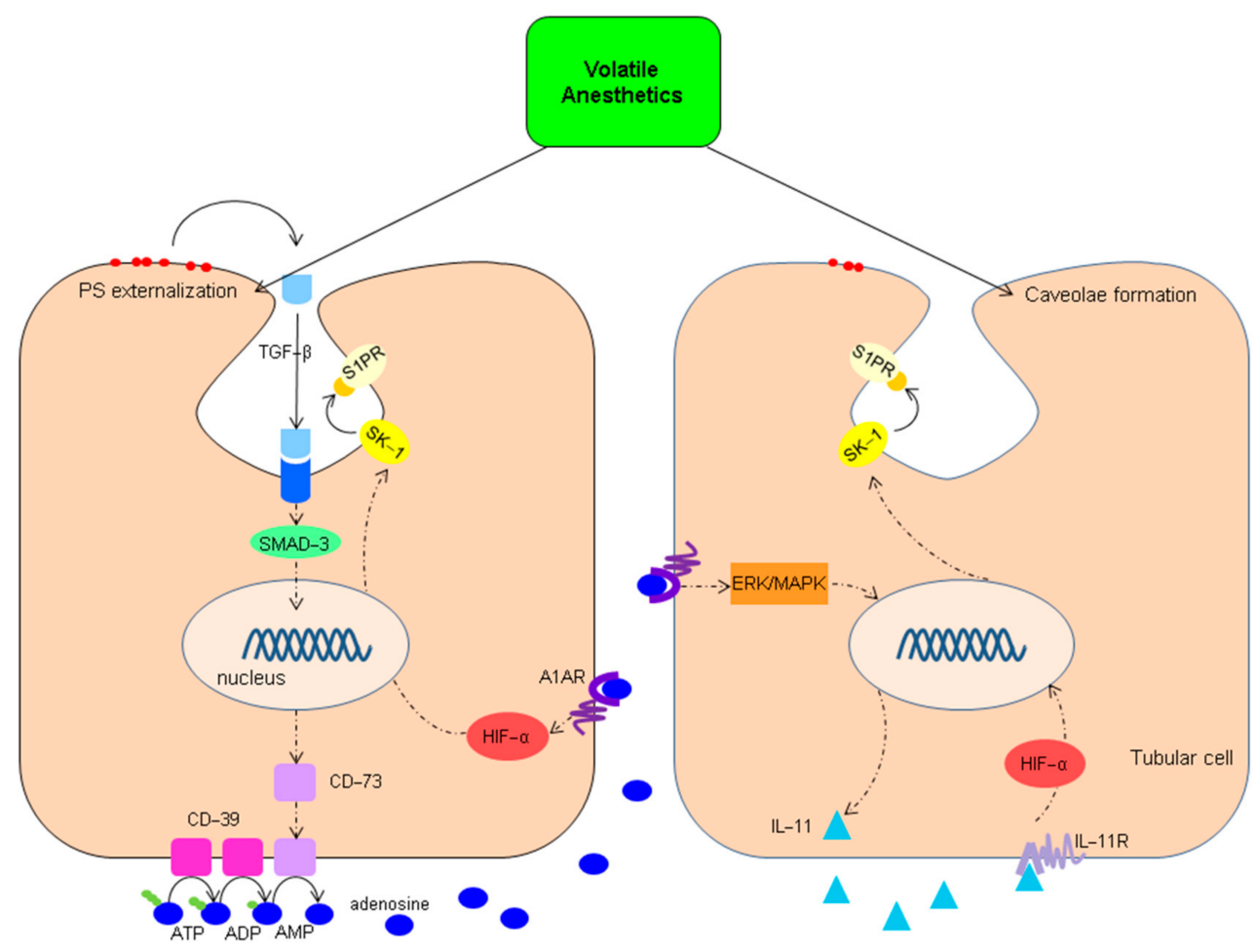

Figure 3. Proposed effect of volatile anesthetics on renal tubular cells and the sphingosine-1-phosphate signaling pathway. Exposure of renal tubular cells leads to the externalization of phosphatidylserine (PS) with a release of transforming growth factor- $\beta$ (TGF- $\beta$ ) and the formation of caveolae with sequestration of key signaling proteins such as TGF- $\beta$ receptors, extracellular regulated kinase (ERK), sphingosine kinase 1 (SK-1) and sphingosine-1-phosphate (S1P). SMAD-3: mothers against decapentaplegic homolog 3; CD: cluster of differentiation; HIF- $\alpha$ : hypoxic inducible factor- $\alpha$; A1AR: A1 adenosine receptor; IL-11: interleukin 11; IL-11R: IL-11 receptor. Adapted from: Fukazawa K, Lee HT. Volatile anesthetics and AKI: risks, mechanisms, and a potential therapeutic window. J. Am. Soc. Nephrol. 2014 May; 25(5):884-892. doi:10.1681/ASN.2013111215.

\subsection{Effect on Circulating Immune Cells}

We have described the role of specific cells and systems of the innate and adaptive immune system in IRI and kidney transplantation [3]. IRI is accompanied by sterile inflammation in which the innate as well as the adaptive immune systems are involved. DAMPs are endogenous molecules released from injured or dying cells or the extracellular matrix. They can originate from the nucleus, cytosol, cell membrane, mitochondria, etc., and can be protein or non-protein. DAMPs are an important trigger for activation of the innate immune system by binding to PRRs such as TLRs and receptors of the complement system. This already starts in the donor $[117,118]$. According to the "danger model", the presence of danger, reflected in cell stress or injury and thus release of DAMPs, is the major factor that induces (allo)immunity, rather than the presence of non-self-tissue [119,120]. The impact of IRI on the activation of both $\mathrm{T}$ and $\mathrm{B}$ cells in driving humoral injury and rejection in organ transplantation is therefore increasingly recognized [121,122].

VA affect many cells of the immune system. This is either by direct interaction of the drug with the cell, or indirectly by altering environmental conditions; hence, IRI. Many of these effects, summarized in Table 1, seem favorable during (kidney) transplantation. Most studies addressing the effects of anesthetic agents on the immune system, however, are in vitro experiments or animal studies. Unfortunately, these results are not directly 
translational to the clinical setting; however, clinical trials looking into the effect of different anesthetic agents or techniques on circulating immune cells, mostly in the field of oncological surgery, are emerging (NCT03193710, NCT03431532, NCT02567942).

Table 1. Effects of volatile anesthetics on various cells of the immune system.

\begin{tabular}{|c|c|}
\hline Cell Type & Effect \\
\hline \multicolumn{2}{|l|}{ Innate immune system } \\
\hline Neutrophils & $\begin{array}{c}\downarrow \text { cellular function } \\
\downarrow \text { ROS production } \\
\downarrow \text { expression of endothelial adhesion molecules } \\
\downarrow \text { adhesion to endothelium } \\
\downarrow \text { tissue infiltration }\end{array}$ \\
\hline Monocytes/macrophages & $\begin{array}{c}\downarrow \text { number } \\
\downarrow \text { release proinflammatory cytokines IL-1 } \beta, \text { TNF- } \alpha, \text { IL-6, IL-8 } \\
\uparrow \text { expression iNOS and NO production } \\
\text { Influence on APC function unknown }\end{array}$ \\
\hline Natural Killer cells & $\begin{array}{c}\downarrow \downarrow \text { cytotoxicity } \\
\downarrow \text { release proinflammatory cytokines }\end{array}$ \\
\hline Dendritic cells & Unknown \\
\hline \multicolumn{2}{|l|}{ Adaptive immune system } \\
\hline T cells & $\begin{array}{c}\downarrow \text { number and proliferation } \\
\downarrow \text { Th1/Th2 ratio } \\
\text { Induction apoptosis } \\
\downarrow \text { release proinflammatory cytokines } \\
\downarrow \text { adhesion molecules }\end{array}$ \\
\hline B cells & $\begin{array}{c}\downarrow \text { number } \\
\text { Induction B cell injury }\end{array}$ \\
\hline T regs & Unknown \\
\hline
\end{tabular}

ROS: reactive oxygen species; IL-1 $\beta$ : interleukin $1 \beta$, TNF- $\alpha$; tumor necrosis factor- $\alpha$; IL-6: interleukin 6; IL-8 interleukin 8; iNOS: inducible nitric oxide synthase; NO: nitric oxide; APC; antigen presenting cell; Th1: T helper cell 1, Th2: T helper cell 2; T regs: regulatory T cell.

\subsubsection{Innate Immunity}

The innate, or non-specific, immune system is evolutionary the oldest part of the immune system. It acts on injury with a fast, short-lasting, and non-specific response, and comprises different cells and systems. Members of this response, such as neutrophils and macrophages, are already involved in the early stage of IRI.

Neutrophils are regarded as primary mediators of injury. Upon reperfusion, these cells adhere to the endothelium and migrate into the graft where they release proinflammatory cytokines, such as interleukin (IL)-4, IL-6, TNF- $\alpha$, interferon (IFN)- $\gamma$, ROS and proteases, leading to injury of the graft and chemotaxis of other immune cells [123]. VA have shown to impair the function of neutrophils and decrease the number of reacting cells. In an in vitro experiment, human neutrophils were exposed to several VA at various concentrations $(0.5$, 1.0 and 2.0 MAC) and were stimulated with bacterial peptides N-formyl-L-methionyl-Lleucyl-phenylalanine (nFMLP) and phorbol-12-myristate-13-acetate (PMA). The presence of halothane, enflurane, and sevoflurane induced an increase in the activation threshold on FMLP stimulation, correlating with reduced $\mathrm{H}_{2} \mathrm{O}_{2}$ (ROS) production. Isoflurane had no effect. The presence of desflurane, however, increased $\mathrm{H}_{2} \mathrm{O}_{2}$ production of neutrophils two-fold, followed by transient suppression of neutrophil function [124]. At clinically relevant concentrations, sevoflurane and isoflurane have been shown to decrease neutrophil adhesion to endothelial cells by inhibiting activation of these neutrophils [125]. In a liver transplantation model in rats, sevoflurane anesthesia attenuated neutrophil-mediated renal 
injury and was associated with decreased neutrophil infiltration and lower levels of TNF- $\alpha$ and IL-6 compared to chloral hydrate anesthesia [126].

Another subset of innate immune cells involved in the early stage of IRI are monocytes and their differentiates, macrophages. Monocyte-macrophages can develop in two distinct subsets, depending on the stimulus. Classically activated macrophages (M1) are induced by cytokines such as IFN- $\gamma$ and microbial products, and are involved in the inflammation and phagocytosis of bacteria, etc. Alternatively, activated macrophages (M2) are induced by IL-4 and Il-13 produced by T helper 2 (Th2) cells and other leucocytes. M2 cells function to control inflammation and are involved in tissue repair and fibrosis [127]. Upon activation, M1 cells release proteolytic enzymes and proinflammatory cytokines such as IL- $1 \beta$, IL6 , IL-8 and TNF- $\alpha$, and IFN- $\gamma$ [128]. The majority of VA have suppressing effects on monocytes and macrophages. Sevoflurane and isoflurane are associated with reduced cytokine concentrations of TNF- $\alpha$, IL1, IL6, IL8 and IL10 [129,130]. The release of IFN- $\gamma$, a Thelper 1 (Th1) cytokine, is involved in the expression of inducible nitric oxide synthase (iNOS) $[131,132]$. Numerous in vivo and in vitro investigations have demonstrated that the inhibition or absence of iNOS was associated with a reduction in IRI $[133,134]$. The effect of VA on iNOS and subsequently on NO production is dependent on different circumstances and the type of VA used. Sevoflurane attenuated NF-kB activation and reduced the expression of iNOS, which was accompanied by a decrease in infarct size and creatine kinase release [135]. In an in vitro experiment, Zha et al. compared the effects of isoflurane, sevoflurane and propofol on macrophage phagocytosis. They demonstrated that isoflurane $(1 \%)$, as well as sevoflurane $(1.5 \%)$, reduced phagocytosis by $50 \%$, while propofol had no significant effect on macrophage phagocytosis [136]. Photo labeling showed that sevoflurane bound to Ras-related protein 1 (Rap1), affecting Rap1 activation, which appeared to be crucial in initiating phagocytosis [136].

Natural killer (NK) cells are the only cells of the innate immune system that originate from the lymphoid cell lineage. Their role in oncological surgery is extensively studied, because NK cells play an important role in first line defense against tumor cells [137]. Their role becomes clearer in kidney transplantation and renal IRI. Zhang and colleagues showed that NK cells can induce tubular cell death in vitro, possibly by interaction of retinoic acid early inducible 1 (RAE-1) on renal tubular cells and natural killer group 2D (NKG2D) receptors on NK cells [138]. In a mouse model, they showed that NK cells quickly infiltrate into the injured kidney following I/R, and that NK cell depletion was protective in this renal IRI model [138]. NK cells have been proven to be directly responsible for tubular epithelial cell injury, which makes them a major contributor to renal IRI [139]. A specific subset of NK cells, invariant NKT (iNKT) cells, infiltrate the kidney 30 min after reperfusion and lead to a significant release of pro-inflammatory cytokines of Th1 cell type (IFN- $\gamma$, TNF- $\alpha$ ) and Th2 cell type (IL4, IL13) [140]. Blocking of iNKT has shown to prevent acute kidney injury (AKI) after IRI [137]. VA have been shown to suppress NK cell cytotoxicity and cytokine-associated NK cell activation [141-143]. Several in vitro studies have demonstrated a decreased response of isoflurane-treated NK cells to IFN- $\gamma$, while sevoflurane is associated with a decreased release of TNF- $\alpha$ [144-146]. Propofol, on the other hand, seems to preserve or enhance the cytotoxicity of NK cells, as shown in an ex vivo stimulation study of NK cells derived from patients with gastric cancer and anesthetized with either propofol or sevoflurane. Propofol, in contrast to sevoflurane, was shown to enhance the cytotoxicity of NK cells [147]. A meta-analysis of the impact of anesthetic exposure on NK cell function, however, showed significant data heterogenicity and was without a conclusive association.

\subsubsection{Adaptive Immunity}

In the case of IRI, CD4+ Th cells as well as CD8+ cytotoxic T cells are found in the kidney and are important mediators of IRI [148-151]. T cell-deficient mice showed attenuated renal IRI, and adoptive $\mathrm{T}$ cell transfer experiments in athymic mice resulted in acute kidney injury (AKI) [152-154]. T cell activation occurs through binding of the 
$\mathrm{T}$ cell receptor (TCR) with a major histocompatibility complex (MHC) on the antigen presenting cell (APC). After activation, $\mathrm{T}$ cells proliferate and differentiate, and might harm the graft through cytokine-mediated inflammation. The effector CD4+ T cells can differentiate into three subtypes; type 1 (Th1), type 2 (Th2) and type 17 (Th17). Of the three CD4+ subtypes, Th1 and Th17 responses are most deleterious. Blockade of $\mathrm{C}-\mathrm{C}$ chemokine receptor type 5 (CCR5), a receptor for chemokine (C-C motif) ligand 5 (CCL5), which is released by Th1 cells, resulted in the protection of kidney IRI in mice models, whereas in a study of Guo et al., Th17 response was increased and activated by an NF- $\mathrm{kB}$ pathway which resulted in aggravated kidney injury after IRI $[155,156]$. The Th2 response entails anti-inflammatory cytokines, which are known to have protective properties against IRI. In mice models without IL4, a mediator of Th2 response, kidney injury was significantly more pronounced [157]. In general, exposure to VA leads to a decreased number and proliferation of T cells. However, not all VA have a comparable effect on T cell response. Conflicting data about the effect of VA on the Th1/Th2 ratio have been published over the years. Exposure to isoflurane did not result in a changed Th1/Th2 ratio in a study of Ren at al., but it was decreased in a study by Inada et al. [158,159]. Sevoflurane was associated with a decreased Th1 concentration, and consequently, a decreased Th1/Th2 ratio [143]. Finally, no differences in Th1/Th2 ratio could be demonstrated with the use of desflurane [160].

Regulatory T cells (Tregs) suppress excessive immune responses and have a potentially promising role in the reduction in IRI [161,162]. Cao Jun et al. concluded that expanded Tregs participated in the repair of the early phase of renal IRI [163]. Little is known about the effects of VA on Tregs. In patients having breast cancer surgery, equipotent doses of propofol and sevoflurane did not result in different CD39, CD73 Treg populations 1 or $24 \mathrm{~h}$ post-surgery [164]. In a randomized controlled trial in LDKT, comparing sevoflurane to desflurane, the use of desflurane induced an increase in peripheral blood Tregs $24 \mathrm{~h}$ post-transplantation [165].

VA might have apoptotic effects on lymphocytes; although consequently they no longer are able perform their immunological function. Isoflurane and sevoflurane directly induce apoptosis in a dose-dependent manner in human peripheral lymphocytes [166]. The induction of apoptosis is accompanied by the increased caspase 3 activity in lymphocytes [167].

While the role of the $\mathrm{T}$ cell may either be protective or pathogenic depending on the subtype of $T$ cell, the role of the B cell in all circumstances is pathogenic during IRI. In a study of Jang et al., B cell trafficking was observed into the allograft during warm kidney IRI and altered tubular repair process [168]. Moreover, the infiltration of B cells is involved in allograft rejection and poor graft survival [169]. Sevoflurane is associated with a decreased number of peripheral blood lymphocytes and splenic B cell counts [170]. However, no differences in the number of $B$ cells were observed between patients receiving propofol or sevoflurane for laparoscopic hysterectomy [171].

\subsubsection{Effect on Lymphocyte Function Antigen-1}

Yuki et al. showed that clinically relevant concentrations of isoflurane and sevoflurane are able to inhibit Lymphocyte Function Antigen-1 (LFA-1) in vitro [172,173]. LFA-1 belongs to the integrin family, a family of adhesion molecules consisting of $\alpha$ and $\beta$ subunits. LFA-1 $(\alpha 1 \beta 2)$ is expressed in all leukocytes. Upon activation of the leukocyte by chemokines or antigens, LFA-1 undergoes conformational changes, facilitating its ability to bind with its ligand, via a process which is called inside-out signaling. The most important ligand for LFA-1 is ICAM-1, of which expression on endothelial cells, APCs and other cells is increased upon IRI. Interaction of LFA-1 with endothelial ICAM-1 assures firm adhesion of the leukocyte to the endothelial cells, and therefore facilitates transmigration of the leukocyte into the interstitium [174]. In the case of NK cells, LFA-1-target cell ICAM-1 interaction is necessary for activation of the NK cell and lysis of the target cell $[175,176]$. LFA-1 activation on T cells facilitates APC binding and is involved in T cell activation (Figure 4). VA agents inhibit LFA-1 at the lovastatin binding site at the $\alpha$ subunit, keeping 
the molecule in the inactive state, and therefore preventing binding of LFA- 1 with its ligand $[172,173]$. Short term blockade of LFA-1 shows promising results in pancreatic islet transplantation in different animal models [177-179]. In humans, efalizumab (Raptiva ${ }^{\circledR}$, Genentech, Merck Serono), a human monocolonal IgG LFA-1 antibody, has been studied in renal transplantation in order to reduce rejection. Efalizumab decreased acute rejection but increased the incidence of post-transplant lymphoproliferative disorder (PTLD) [180]. Due to the presentation of four cases of progressive multifocal leukoencephalopathy in psoriasis patients treated with efalizumab, the drug was taken off the market in 2009 [181]. LFA-1 still remains an attractive target in (kidney) transplantation, not only in the light of immune therapy but also in the reduction in IRI. The question remains as to whether a short-term exposure to VA, only during the transplant procedure, is able to exert beneficial effects on the kidney graft via LFA-1 inhibition. Propofol is also able to inhibit LFA-1 in vitro, but it is unknown whether this is the case in vivo [182]. Extrapolation of in vitro experiments with propofol to the clinical setting might not be straightforward because protein binding of propofol in whole blood is significant, and free propofol concentrations might be significantly lower compared to the concentrations used in in vitro experiments [183].

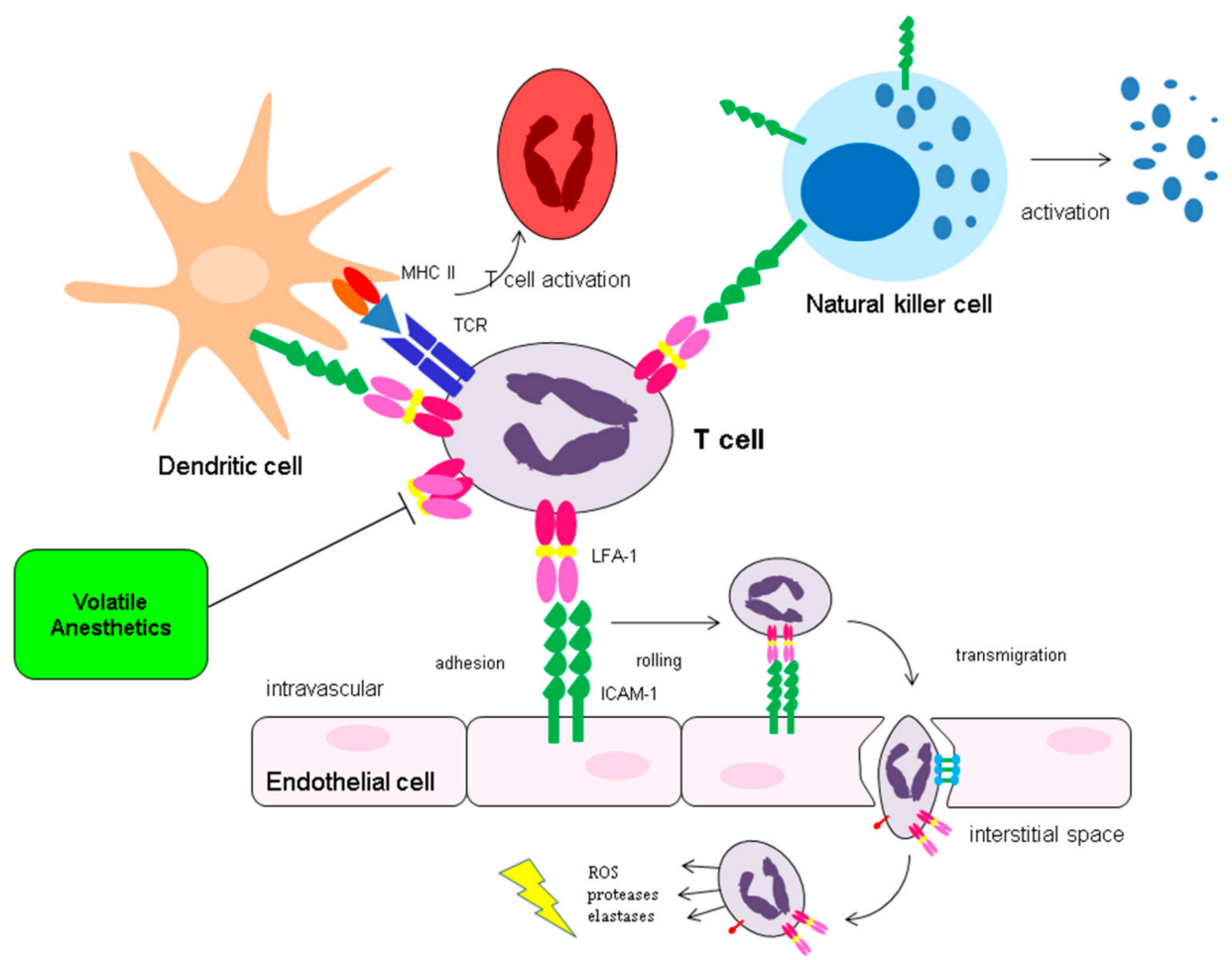

Figure 4. Interaction of LFA-1 with its ligands and consequences. Upon activation of the leukocyte by chemokines or antigens, lymphocyte function antigen-1 (LFA-1) undergoes conformational changes, facilitating its ability to bind with its ligand, via a process which is called inside-out signaling. The most important ligand for LFA-1 is intercellular adhesion molecule 1 (ICAM-1), of which expression on endothelial cells, antigen presenting cells (APCs) and other cells is increased upon IRI. Interaction of LFA-1 with endothelial ICAM-1 assures firm adhesion of the leukocyte to the endothelial cells and facilitates transmigration of the leukocyte into the interstitium. In the case of natural killer (NK) cells, LFA-1-target cell ICAM-1 interaction is necessary for activation of the NK cell and lysis of the target cell. LFA-1 activation on T cells facilitates APC binding and is involved in T cell activation. VA are able to inhibit activation of LFA-1, keeping it in its folded state. MHC-II: major histocompatibility complex II; TCR: T cell receptor. 


\section{Clinical Trials on the Potential of Volatile Anesthetic Protection in Kidney Transplantation}

Only a few clinical trials have looked into the effect of anesthetics used in organ procurement procedures and kidney transplantation on graft outcomes. In a retrospective cohort analysis, Perez-Protto et al. studied the impact of VA during DBD donor organ procurement on graft survival in recipients (preconditioning) and compared VA-exposed ( $n=138)$ to non-VA-exposed ( $n=75$, no anesthetic, etc.) donors [184]. They found no significant differences between the groups in 30-day and five-year graft survival of heart, liver, lung, and kidney transplants. In this analysis, however, sample size was relatively small, and the rates of graft failures in both groups were low ( 25 of the 446 transplanted organs, 5.6\%); consequently, there was a lack of power to confirm conclusions. In addition, the dosage and duration of exposure of the VA were unclear. In prospective cohort analysis, Lee et al. compared kidney function in recipients of living donor kidneys according to the type of anesthetic used in their matching donor (preconditioning) and found no differences between desflurane $(n=50)$ and propofol $(n=49)$ [185]. Changes in serum creatinine post-transplantation and estimated glomerular filtration rate (eGFR) at day of discharge were comparable between groups. In a pilot proof of concept study of the Volatile Anesthetic Protection of Renal transplants (VAPOR) project of our group, we compared a sevoflurane-based anesthesia with a propofol-based anesthesia in living donor kidney transplantation (LDKT) (VAPOR-1 study; pre- and post-conditioning) [186]. Although this specific setting of kidney transplantation is associated with significantly less IRI, low incidence of DGF $(<5 \%)$ and better graft outcome compared to deceased donor kidney transplantation, it provides an elegant research model due to a homogeneous model of IRI and reproducible ischemia times. In addition, this model provides the possibility to treat the donor. The primary outcome measure was a set of urinary biomarkers consisting of kidney injury molecule-1 (KIM-1), N-acetyl-D-glucosaminidase (NAG), and heart-type fatty acid binding protein (H-FABP) reflecting kidney injury with the hypothesis of higher levels in propofol-treated patients. Whereas H-FABP was highest in the first urine sample upon reperfusion and levels were comparable between treatment groups, levels of KIM-1 and NAG increased again the first day after transplantation after an initial decrease. To our surprise, sevoflurane-treated patients showed higher levels of KIM-1 (second day) and NAG (first day, second day) after transplantation compared to propofol-treated patients. This, however, was not associated with inferior graft outcome [182]. In contrast, higher KIM-1 levels the first day after transplantation were significantly associated with better eGFR one month post-transplantation $(R=0.412, p=0.002)$, which was almost the case for KIM-1 levels measured the second day after transplantation $(p=0.074)$. This could be due to the opposed dual role of KIM-1, with evidence that in acute renal injury, KIM-1 plays a role in the regeneration and repair process. AKI surviving PTC expressing KIM-1 are able to phagocytize luminal cellular debris consisting of apoptotic and necrotic cells, enabling the PTC to down-regulate the innate immune response upon AKI, which could be beneficial in kidney transplantation $[187,188]$. Higher NAG levels (first and second in this case) might be a reflection of regenerated tubular cells showing baseline lysosomal activity rather than a reflection of injury. An intriguing outcome of our study was the difference in incidence of $\mathrm{T}$ cell mediated rejection during a two-year follow-up in favor of sevoflurane-treated patients. This, however, was not our primary outcome measure, and the number of events and patients ( $n=9, n=57$, respectively) did not allow us to perform a multivariate analysis. Well-designed randomized controlled trials (RCTs) need to be performed to see whether the effects of VA are clinically relevant and are attributable to improved outcome after kidney transplantation. One can hypothesize that the potential beneficial effects are more pronounced in the setting of deceased donor kidney transplantation, because the extent of IRI in this setting exceeds the amount encountered in LDKT. Currently, VAPOR-2, an international multicenter RCT (ClinicalTrials.gov: NCT02727296), in which 488 patients receiving a DBD or DCD kidney will be randomized to a sevoflurane-remifentanil-based anesthesia or a propofol-remifentanil-based anesthesia (post-conditioning), is running. 
The primary outcome in this study is DGF, an adequate reflection of IRI. After completion of the VAPOR project, we hope to be able to answer the question as to whether the choice of anesthetics contributes to improved graft and patient outcome after kidney transplantation.

Which type of VA confers the most protective effect is disputed. In the animal experiments of Lee et al., isoflurane and sevoflurane showed comparable effects but were significantly more profound than desflurane [42]. This could be due to the fact that desflurane has a lower lipid solubility. Interaction of the VA with the bi-lipid membranes of cells and organelles has been proposed as a potential point of engagement of the protective effects of these agents. Park et al. retrospectively compared the effect of desflurane ( $n=71)$ and sevoflurane $(n=73)$ in living kidney donors and their matching recipients (pre- and post-conditioning). They found no differences between both anesthetics in terms of eGFR, creatinine and blood urea nitrogen (BUN) one year post-transplantation, as was the case for DGF, AR and graft failure [189]. Similar findings were found by Savran Karadeniz et al., in a prospective cohort analysis comparing desflurane $(n=30)$ and sevoflurane $(n=35)$ [190]. Although sevoflurane anesthesia was associated with higher IL-8 levels one day and one week after transplantation, both agents had similar effects on graft function [190].

\section{Summary}

Animal and in vitro experiments in various organs demonstrate that VA interfere with many of the processes underlying the pathophysiology of IRI encountered in kidney transplantation. Introduction of VA before ischemia or directly upon reperfusion can prevent opening of the $\mathrm{mPTP}$, an important initiating step in the injurious cascade of IRI. In addition, VA have been shown to prevent degradation of glycocalyx and preserve this important barrier of the endothelium. Both pre- and post-conditioning were found to be associated with upregulation of the HIF $\alpha$ subunit and improved organ function after I/R. Above this, VA affect many cells of the innate as well as the adaptive immune system, either by direct interaction with the cell or indirectly by altering environmental conditions; hence, IRI. Many of these effects seem favorable during (kidney) transplantation. Altogether, VA potentially could have a protective effect against the consequences of IRI and improve graft outcome in kidney transplantation. These effects, however, are dose-, time-, organ-, and contextdependent, and are not necessarily translational to clinical practice. It is key for future benefit of our patients that we exceed with well-designed clinical trials to explore whether these protective effects are clinically relevant in patients with all kinds of comorbidities, multiple medications, and genetic variation, while at the same time proceeding with further unraveling of underlying mechanistic pathways.

Author Contributions: Conceptualization, G.J.N.-M.; writing—original draft preparation, G.J.N.-M and D.J.B.; writing—review and editing, H.G.D.L.; visualization, G.J.N.-M.; All authors have read and agreed to the published version of the manuscript.

Funding: This research received no external funding.

Conflicts of Interest: The authors declare no conflict of interest.

\section{References}

1. Siedlecki, A.; Irish, W.; Brennan, D.C. Delayed Graft Function in the Kidney Transplant. Am. J. Transplant. 2011, 11, 2279-2296. [CrossRef] [PubMed]

2. Snoeijs, M.G.J.; Winkens, B.; Heemskerk, M.B.A.; Hoitsma, A.J.; Christiaans, M.H.L.; Buurman, W.A.; van Heurn, L.W.E. Kidney Transplantation From Donors After Cardiac Death: A 25-Year Experience. Transplantation 2010, 90, 1106-1112. [CrossRef] [PubMed]

3. Nieuwenhuijs-Moeke, G.J.; Pischke, S.E.; Berger, S.P.; Sanders, J.S.F.; Pol, R.A.; Struys, M.M.R.F.; Ploeg, R.J.; Leuvenink, H.G.D. Ischemia and Reperfusion Injury in Kidney Transplantation: Relevant Mechanisms in Injury and Repair. J. Clin. Med. 2020, 9, 253. [CrossRef]

4. Meissner, M.; Viehmann, S.F.; Kurts, C. DAMPening sterile inflammation of the kidney. Kidney Int. 2019, 95, 489-491. [CrossRef] [PubMed]

5. Eltzschig, H.K.; Eckle, T. Ischemia and reperfusion-from mechanism to translation. Nat. Med. 2011, 17, 1391-1401. [CrossRef] 
6. Gunaratnam, L.; Bonventre, J.V. HIF in Kidney Disease and Development. J. Am. Soc. Nephrol. 2008, 20, 1877-1887. [CrossRef] [PubMed]

7. Murry, C.E.; Jennings, R.B.; Reimer, K.A. Preconditioning with Ischemia: A Delay of Lethal Cell Injury in Ischemic Myocardium. Circulation 1986, 74, 1124-1136. [CrossRef] [PubMed]

8. Heusch, G. Molecular Basis of Cardioprotection. Circ. Res. 2015, 116, 674-699. [CrossRef]

9. Crimi, G.; Pica, S.; Raineri, C.; Bramucci, E.; De Ferrari, G.M.; Klersy, C.; Ferlini, M.; Marinoni, B.; Repetto, A.; Romeo, M.; et al. Remote Ischemic Post-Conditioning of the Lower Limb During Primary Percutaneous Coronary Intervention Safely Reduces Enzymatic Infarct Size in Anterior Myocardial Infarction. JACC Cardiovasc. Interv. 2013, 6, 1055-1063. [CrossRef]

10. Czigány, Z.; Turóczi, Z.; Ónody, P.; Harsányi, L.; Lotz, G.; Hegedüs, V.; Szijártó, A. Remote Ischemic Perconditioning Protects the Liver from Ischemia-Reperfusion Injury. J. Surg. Res. 2013, 185, 605-613. [CrossRef] [PubMed]

11. Song, S.-Q.; Gan, H.-L.; Zhang, J.-Q.; Feng, L.; Sun, J.-C.; Wang, S.-X. Post-Conditioning through Lower Limb IschemiaReperfusion Can Alleviate Lung Ischemia-Reperfusion Injury. Int. J. Clin. Exp. Med. 2015, 8, 14953-14961. [PubMed]

12. Wang, Y.; Reis, C.; Applegate, R.; Stier, G.; Martin, R.; Zhang, J.H. Ischemic Conditioning-Induced Endogenous Brain Protection: Applications Pre-, per- or Post-Stroke. Exp. Neurol. 2015, 272, 26-40. [CrossRef]

13. Wu, H.-H.; Hsiao, T.-Y.; Chien, C.-T.; Lai, M.-K. Ischemic Conditioning by Short Periods of Reperfusion Attenuates Renal Ischemia/Reperfusion Induced Apoptosis and Autophagy in the Rat. J. Biomed. Sci. 2009, 16, 19. [CrossRef] [PubMed]

14. Yamashita, N.; Hoshida, S.; Otsu, K.; Taniguchi, N.; Kuzuya, T.; Hori, M. Involvement of Cytokines in the Mechanism of Whole-Body Hyperthermia-Induced Cardioprotection. Circulation 2000, 102, 452-457. [CrossRef]

15. Szekeres, L.; Papp, J.G.; Szilvassy, Z.; Udvary, E.; Vegh, A. Moderate Stress by Cardiac Pacing May Induce Both Short Term and Long Term Cardioprotection. Cardiovasc. Res. 1993, 27, 593-596. [CrossRef] [PubMed]

16. Kalenka, A.; Maurer, M.H.; Feldmann, R.E.; Kuschinsky, W.; Waschke, K.F. Volatile Anesthetics Evoke Prolonged Changes in the Proteome of the Left Ventricule Myocardium: Defining a Molecular Basis of Cardioprotection? Acta Anaesthesiol. Scand. 2006, 50, 414-427. [CrossRef]

17. Lin, D.; Li, G.; Zuo, Z. Volatile Anesthetic Post-Treatment Induces Protection via Inhibition of Glycogen Synthase Kinase $3 \beta$ in Human Neuron-like Cells. Neuroscience 2011, 179, 73-79. [CrossRef] [PubMed]

18. Shen, J.-T.; Li, Y.-S.; Xia, Z.-Q.; Wen, S.-H.; Yao, X.; Yang, W.-J.; Li, C.; Liu, K.-X. Remifentanil Preconditioning Protects the Small Intestine against Ischemia/Reperfusion Injury via Intestinal $\delta$ - and $\mu$-Opioid Receptors. Surgery 2016, 159, 548-559. [CrossRef]

19. Liu, X.; Pan, Z.; Su, D.; Yang, Z.; Zheng, B.; Wang, X.; Tian, J. Remifentanil Ameliorates Liver Ischemia-Reperfusion Injury Through Inhibition of Interleukin-18 Signaling. Transplantation 2015, 99, 2109-2117. [CrossRef]

20. Nguyen, A.Q.; Cherry, B.H.; Scott, G.F.; Ryou, M.-G.; Mallet, R.T. Erythropoietin: Powerful Protection of Ischemic and PostIschemic Brain. Exp. Biol. Med. 2014, 239, 1461-1475. [CrossRef]

21. Ahmed, L.A.; Salem, H.A.; Attia, A.S.; Agha, A.M. Pharmacological Preconditioning with Nicorandil and Pioglitazone Attenuates Myocardial Ischemia/Reperfusion Injury in Rats. Eur. J. Pharmacol. 2011, 663, 51-58. [CrossRef] [PubMed]

22. Gaylord, H.; Simpson, B. The Effect of Certain Anesthetics and Loss of Blood upon the Growth of Transplanted Mouse Cancer. J. Cancer Res. 1916, 1, 379-382.

23. Graham, E.A. The Influence of Ether and Ether Anesthesia on Bacteriolysis, Agglutination, and Phagocytosis. J. Infect. Dis. 1911, 8, 147-175. [CrossRef]

24. Urner, M.; Limbach, L.K.; Herrmann, I.K.; Müller-Edenborn, B.; Roth-Z'Graggen, B.; Schlicker, A.; Reyes, L.; Booy, C.; Hasler, M.; Stark, W.J.; et al. Fluorinated Groups Mediate the Immunomodulatory Effects of Volatile Anesthetics in Acute Cell Injury. Am. J. Respir. Cell Mol. Biol. 2011, 45, 617-624. [CrossRef] [PubMed]

25. Bland, J.H.L.; Lowenstein, E. Halothane-Induced Decrease in Experimental Myocardial Ischemia in the Non-Failing Canine Heart. Anesthesiology 1976, 45, 287-292. [CrossRef]

26. Warltier, D.C.; Al-Wathiqui, M.H.; Kampine, J.P.; Schmeling, W.T. Recovery of Contractile Function of Stunned Myocardium in Chronically Instrumented Dogs Is Enhanced by Halothane or Isoflurane. Anesthesiology 1988, 69, 552-565. [CrossRef]

27. Jiao, X.; Lin, X.; Ni, X.; Li, H.; Zhang, C.; Yang, C.; Song, H.; Yi, Q.; Zhang, L. Volatile Anesthetics versus Total Intravenous Anesthesia in Patients Undergoing Coronary Artery Bypass Grafting: An Updated Meta-Analysis and Trial Sequential Analysis of Randomized Controlled Trials. PLoS ONE 2019, 14, e0224562. [CrossRef] [PubMed]

28. Symons, J.A.; Myles, P.S. Myocardial Protection with Volatile Anaesthetic Agents during Coronary Artery Bypass Surgery: A Meta-Analysis. Br. J. Anaesth. 2006, 97, 127-136. [CrossRef] [PubMed]

29. Landoni, G.; Greco, T.; Biondi-Zoccai, G.; Nigro Neto, C.; Febres, D.; Pintaudi, M.; Pasin, L.; Cabrini, L.; Finco, G.; Zangrillo, A. Anaesthetic Drugs and Survival: A Bayesian Network Meta-Analysis of Randomized Trials in Cardiac Surgery. Br. J. Anaesth. 2013, 111, 886-896. [CrossRef]

30. Bonanni, A.; Signori, A.; Alicino, C.; Mannucci, I.; Grasso, M.A.; Martinelli, L.; Deferrari, G. Volatile Anesthetics versus Propofol for Cardiac Surgery with Cardiopulmonary Bypass. Anesthesiology 2020, 132, 1429-1446. [CrossRef]

31. Li, Q.F.; Zhu, Y.S.; Jiang, H.; Xu, H.; Sun, Y. Isoflurane Preconditioning Ameliorates Endotoxin-Induced Acute Lung Injury and Mortality in Rats. Anesth. Analg. 2009, 109, 1591-1597. [CrossRef] [PubMed]

32. Ohsumi, A.; Marseu, K.; Slinger, P.; McRae, K.; Kim, H.; Guan, Z.; Hwang, D.M.; Liu, M.; Keshavjee, S.; Cypel, M. Sevoflurane Attenuates Ischemia-Reperfusion Injury in a Rat Lung Transplantation Model. Ann. Thorac. Surg. 2017, 103, 1578-1586. [CrossRef] [PubMed] 
33. Casanova, J.; Simon, C.; Vara, E.; Sanchez, G.; Rancan, L.; Abubakra, S.; Calvo, A.; Gonzalez, F.J.; Garutti, I. Sevoflurane Anesthetic Preconditioning Protects the Lung Endothelial Glycocalyx from Ischemia Reperfusion Injury in an Experimental Lung Autotransplant Model. J. Anesth. 2016, 30, 755-762. [CrossRef]

34. Figueira, E.R.R.; Rocha-Filho, J.A.; Lanchotte, C.; Coelho, A.M.M.; Nakatani, M.; Tatebe, E.R.; Lima, J.A.V.; Mendes, C.O.; de Araujo, B.C.R.P.; Abdo, E.E.; et al. Sevoflurane Preconditioning plus Postconditioning Decreases Inflammatory Response with Hemodynamic Recovery in Experimental Liver Ischemia Reperfusion. Gastroenterol. Res. Pract. 2019, 2019, 5758984. [CrossRef] [PubMed]

35. Beck-Schimmer, B.; Roth Z'graggen, B.; Booy, C.; Köppel, S.; Spahn, D.R.; Schläpfer, M.; Schadde, E. Sevoflurane Protects Hepatocytes From Ischemic Injury by Reducing Reactive Oxygen Species Signaling of Hepatic Stellate Cells. Anesth. Analg. 2018, 127, 1058-1065. [CrossRef]

36. Zhou, S.-P.; Jiang, P.; Liu, L.; Liu, H. Protective Effect of Sevoflurane on Hepatic Ischaemia/Reperfusion Injury in the Rat. Eur. J. Anaesthesiol. 2013, 30, 612-617. [CrossRef]

37. Zhu, Y.-M.; Gao, X.; Ni, Y.; Li, W.; Kent, T.A.; Qiao, S.-G.; Wang, C.; Xu, X.-X.; Zhang, H.-L. Sevoflurane Postconditioning Attenuates Reactive Astrogliosis and Glial Scar Formation after Ischemia-Reperfusion Brain Injury. Neuroscience 2017, 356, 125-141. [CrossRef] [PubMed]

38. Wen, X.-R.; Fu, Y.-Y.; Liu, H.-Z.; Wu, J.; Shao, X.-P.; Zhang, X.-B.; Tang, M.; Shi, Y.; Ma, K.; Zhang, F.; et al. Neuroprotection of Sevoflurane against Ischemia/Reperfusion-Induced Brain Injury through Inhibiting JNK3/Caspase-3 by Enhancing Akt Signaling Pathway. Mol. Neurobiol. 2015, 53, 1661-1671. [CrossRef]

39. Zhong, H.; Chen, H.; Gu, C. Sevoflurane Post-Treatment Upregulated MiR-203 Expression to Attenuate Cerebral IschemiaReperfusion-Induced Neuroinflammation by Targeting MyD88. Inflammation 2020, 43, 651-663. [CrossRef] [PubMed]

40. Lee, H.T.; Chen, S.W.C.; Doetschman, T.C.; Deng, C.; D’Agati, V.D.; Kim, M. Sevoflurane Protects against Renal Ischemia and Reperfusion Injury in Mice via the Transforming Growth Factor-B1 Pathway. Am. J. Physiol. Ren. Physiol. 2008, 295, F128-F136. [CrossRef] [PubMed]

41. Lee, H.T.; Kim, M.; Song, J.H.; Chen, S.W.C.; Gubitosa, G.; Emala, C.W. Sevoflurane-Mediated TGF-B1 Signaling in Renal Proximal Tubule Cells. Am. J. Physiol. Ren. Physiol. 2008, 294, F371-F378. [CrossRef] [PubMed]

42. Lee, H.T.; Ota-Setlik, A.; Fu, Y.; Nasr, S.H.; Emala, C.W. Differential Protective Effects of Volatile Anesthetics against Renal Ischemia-Reperfusion Injury In Vivo. Anesthesiology 2004, 101, 1313-1324. [CrossRef]

43. Lee, H.T.; Kim, M.; Kim, M.; Kim, N.; Billings, F.T.; D’Agati, V.D.; Emala, C.W. Isoflurane Protects against Renal Ischemia and Reperfusion Injury and Modulates Leukocyte Infiltration in Mice. Am. J. Physiol. Ren. Physiol. 2007, 293, F713-F722. [CrossRef]

44. Ko, J.S.; Gwak, M.S.; Choi, S.J.; Kim, G.S.; Kim, J.A.; Yang, M.; Lee, S.M.; Cho, H.S.; Chung, I.S.; Kim, M.H. The Effects of Desflurane and Propofol-Remifentanil on Postoperative Hepatic and Renal Functions after Right Hepatectomy in Liver Donors. Liver Transplant. 2008, 14, 1150-1158. [CrossRef]

45. Martin, J.L.; Gruszczyk, A.V.; Beach, T.E.; Murphy, M.P.; Saeb-Parsy, K. Mitochondrial Mechanisms and Therapeutics in Ischaemia Reperfusion Injury. Pediatr. Nephrol. 2018, 34, 1167-1174. [CrossRef] [PubMed]

46. Riess, M.L.; Eells, J.T.; Kevin, L.G.; Camara, A.K.S.; Henry, M.M.; Stowe, D.F. Attenuation of Mitochondrial Respiration by Sevoflurane in Isolated Cardiac Mitochondria Is Mediated in Part by Reactive Oxygen Species. Anesthesiology 2004, 100, 498-505. [CrossRef] [PubMed]

47. Riess, M.L.; Kevin, L.G.; McCormick, J.; Jiang, M.T.; Rhodes, S.S.; Stowe, D.F. Anesthetic Preconditioning: The Role of Free Radicals in Sevoflurane-Induced Attenuation of Mitochondrial Electron Transport in Guinea Pig Isolated Hearts. Anesth. Analg. 2005, 100, 46-53. [CrossRef]

48. Paradies, G.; Petrosillo, G.; Pistolese, M.; Di Venosa, N.; Federici, A.; Ruggiero, F.M. Decrease in Mitochondrial Complex I Activity in Ischemic/Reperfused Rat Heart. Circ. Res. 2004, 94, 53-59. [CrossRef] [PubMed]

49. Kevin, L.G.; Novalija, E.; Riess, M.L.; Camara, A.K.S.; Rhodes, S.S.; Stowe, D.F. Sevoflurane Exposure Generates Superoxide but Leads to Decreased Superoxide During Ischemia and Reperfusion in Isolated Hearts. Anesth. Analg. 2003, 96, 949-955. [CrossRef]

50. Novalija, E.; Kevin, L.G.; Camara, A.K.S.; Bosnjak, Z.J.; Kampine, J.P.; Stowe, D.F. Reactive Oxygen Species Precede the $\varepsilon$ Isoform of Protein Kinase C in the Anesthetic Preconditioning Signaling Cascade. Anesthesiology 2003, 99, 421-428. [CrossRef] [PubMed]

51. Yao, Y.; Fang, N.; Shi, C.; Li, L. Sevoflurane Postconditioning Protects Isolated Rat Hearts against Ischemia-Reperfusion Injury. Chin. Med. J. 2010, 123, 1320-1328. [PubMed]

52. Hausenloy, D.J.; Tsang, A.; Yellon, D.M. The reperfusion injury salvage kinase pathway: A common target for both ischemic preconditioning and postconditioning. Trends Cardiovasc. Med. 2005, 15, 69-75. [CrossRef] [PubMed]

53. Andrews, D.T.; Royse, C.F.; Royse, A.G. The Mitochondrial Permeability Transition Pore and Its Role in Anaesthesia-Triggered Cellular Protection during Ischaemia-Reperfusion Injury. Anaesth. Intensive Care 2012, 40, 46-70. [CrossRef] [PubMed]

54. Argaud, L.; Gateau-Roesch, O.; Raisky, O.; Loufouat, J.; Robert, D.; Ovize, M. Postconditioning Inhibits Mitochondrial Permeability Transition. Circulation 2005, 111, 194-197. [CrossRef]

55. Lemoine, S.; Zhu, L.; Beauchef, G.; Lepage, O.; Babatasi, G.; Ivascau, C.; Massetti, M.; Galera, P.; Gérard, J.-L.; Hanouz, J.-L. Role of 70-KDa Ribosomal Protein S6 Kinase, Nitric Oxide Synthase, Glycogen Synthase Kinase-3 $\beta$, and Mitochondrial Permeability Transition Pore in Desflurane-Induced Postconditioning in Isolated Human Right Atria. Anesthesiology 2010, 112, 1355-1363. [CrossRef] 
56. Yao, Y.-T.; Li, L.-H.; Chen, L.; Wang, W.-P.; Li, L.-B.; Gao, C.-Q. Sevoflurane Postconditioning Protects Isolated Rat Hearts against Ischemia-Reperfusion Injury: The Role of Radical Oxygen Species, Extracellular Signal-Related Kinases 1/2 and Mitochondrial Permeability Transition Pore. Mol. Biol. Rep. 2009, 37, 2439-2446. [CrossRef]

57. Yao, Y.; Li, L.; Li, L.; Gao, C.; Shi, C. Sevoflurane Postconditioning Protects Chronically-Infarcted Rat Hearts against IschemiaReperfusion Injury by Activation of Pro-Survival Kinases and Inhibition of Mitochondrial Permeability Transition Pore Opening upon Reperfusion. Biol. Pharm. Bull. 2009, 32, 1854-1861. [CrossRef] [PubMed]

58. Krolikowski, J.G.; Weihrauch, D.; Bienengraeber, M.; Kersten, J.R.; Warltier, D.C.; Pagel, P.S. Role of Erk1/2, P70s6K, and ENOS in Isofluraneinduced Cardioprotection during Early Reperfusionin Vivo. Can. J. Anesth. J. Can. Anesthésie 2006, 53, 174-182. [CrossRef]

59. Ge, Z.-D.; Pravdic, D.; Bienengraeber, M.; Pratt, P.F.; Auchampach, J.A.; Gross, G.J.; Kersten, J.R.; Warltier, D.C. Isoflurane Postconditioning Protects against Reperfusion Injury by Preventing Mitochondrial Permeability Transition by an Endothelial Nitric Oxide Synthase-Dependent Mechanism. Anesthesiology 2010, 112, 73-85. [CrossRef]

60. Venkatapuram, S.; Wang, C.; Krolikowski, J.G.; Weihrauch, D.; Kersten, J.R.; Warltier, D.C.; Pratt, P.F.; Pagel, P.S. Inhibition of Apoptotic Protein P53 Lowers the Threshold of Isoflurane-Induced Cardioprotection During Early Reperfusion in Rabbits. Anesth. Analg. 2006, 103, 1400-1405. [CrossRef] [PubMed]

61. Pagel, P.S.; Krolikowski, J.G.; Neff, D.A.; Weihrauch, D.; Bienengraeber, M.; Kersten, J.R.; Warltier, D.C. Inhibition of Glycogen Synthase Kinase Enhances Isoflurane-Induced Protection Against Myocardial Infarction During Early Reperfusion In Vivo. Anesth. Analg. 2006, 102, 1348-1354. [CrossRef] [PubMed]

62. Lecour, S. Activation of the protective Survivor Activating Factor Enhancement (SAFE) pathway against reperfusion injury: Does it go beyond the RISK pathway? J. Mol. Cell Cardiol. 2009, 47, 32-40. [CrossRef]

63. Wang, J.-K.; Yu, L.-N.; Zhang, F.-J.; Yang, M.-J.; Yu, J.; Yan, M.; Chen, G. Postconditioning with Sevoflurane Protects against Focal Cerebral Ischemia and Reperfusion Injury via PI3K/Akt Pathway. Brain Res. 2010, 1357, 142-151. [CrossRef]

64. Yu, L.; Yu, J.; Zhang, F.; Yang, M.; Ding, T.; Wang, J.; He, W.; Fang, T.; Chen, G.; Yan, M. Sevoflurane Postconditioning Reduces Myocardial Reperfusion Injury in Rat Isolated Hearts via Activation of PI3K/Akt Signaling and Modulation of Bcl-2 Family Proteins. J. Zhejiang Univ. Sci. B 2010, 11, 661-672. [CrossRef] [PubMed]

65. Wang, C.; Neff, D.A.; Krolikowski, J.G.; Weihrauch, D.; Bienengraeber, M.; Warltier, D.C.; Kersten, J.R.; Pagel, P.S. The Influence of B-Cell Lymphoma 2 Protein, an Antiapoptotic Regulator of Mitochondrial Permeability Transition, on Isoflurane-Induced and Ischemic Postconditioning in Rabbits. Anesth. Analg. 2006, 102, 1355-1360. [CrossRef]

66. Wu, W.; Zhou, X.; Liu, P.; Fei, W.; Li, L.; Yun, H. Isoflurane Reduces Hypoxia/Reoxygenation-Induced Apoptosis and Mitochondrial Permeability Transition in Rat Primary Cultured Cardiocytes. BMC Anesthesiol. 2014, 14, 17. [CrossRef] [PubMed]

67. Pravdic, D.; Mio, Y.; Sedlic, F.; Pratt, P.; Warltier, D.; Bosnjak, Z.; Bienengraeber, M. Isoflurane Protects Cardiomyocytes and Mitochondria by Immediate and Cytosol-Independent Action at Reperfusion. Br. J. Pharmacol. 2010, 160, 220-232. [CrossRef]

68. Cohen, M.V.; Yang, X.-M.; Downey, J.M. Acidosis, Oxygen, and Interference with Mitochondrial Permeability Transition Pore Formation in the Early Minutes of Reperfusion Are Critical to Postconditioning's Success. Basic Res. Cardiol. 2008, 103, 464-471. [CrossRef] [PubMed]

69. Inserte, J.; Barba, I.; Hernando, V.; Abellan, A.; Ruiz-Meana, M.; Rodriguez-Sinovas, A.; Garcia-Dorado, D. Effect of Acidic Reperfusion on Prolongation of Intracellular Acidosis and Myocardial Salvage. Cardiovasc. Res. 2007, 77, 782-790. [CrossRef]

70. Abad, M.F.C.; Di Benedetto, G.; Magalhães, P.J.; Filippin, L.; Pozzan, T. Mitochondrial PH Monitored by a New Engineered Green Fluorescent Protein Mutant. J. Biol. Chem. 2003, 279, 11521-11529. [CrossRef]

71. Brennan, J.; Berry, R.; Baghai, M.; Duchen, M.; Shattock, M. FCCP Is Cardioprotective at Concentrations That Cause Mitochondrial Oxidation without Detectable Depolarisation. Cardiovasc. Res. 2006, 72, 322-330. [CrossRef]

72. Dlasková, A.; Hlavatá, L.; Ježek, J.; Ježek, P. Mitochondrial Complex I Superoxide Production Is Attenuated by Uncoupling. Int. J. Biochem. Cell Biol. 2008, 40, 2098-2109. [CrossRef]

73. Becker, B.F.; Chappell, D.; Bruegger, D.; Annecke, T.; Jacob, M. Therapeutic Strategies Targeting the Endothelial Glycocalyx: Acute Deficits, but Great Potential. Cardiovasc. Res. 2010, 87, 300-310. [CrossRef]

74. Ebong, E.E.; Macaluso, F.P.; Spray, D.C.; Tarbell, J.M. Imaging the Endothelial Glycocalyx In Vitro by Rapid Freezing/Freeze Substitution Transmission Electron Microscopy. Arterioscler. Thromb. Vasc. Biol. 2011, 31, 1908-1915. [CrossRef] [PubMed]

75. Becker, B.F.; Chappell, D.; Jacob, M. Endothelial Glycocalyx and Coronary Vascular Permeability: The Fringe Benefit. Basic Res. Cardiol. 2010, 105, 687-701. [CrossRef] [PubMed]

76. Danielli, J.F. Capillary Permeability and Oedema in the Perfused Frog. J. Physiol. 1940, 98, 109-129. [CrossRef] [PubMed]

77. Pries, A.R.; Secomb, T.W.; Gaehtgens, P. The Endothelial Surface Layer. Pflügers Arch. Eur. J. Physiol. 2000, 440, 653-666. [CrossRef] [PubMed]

78. Becker, B.F.; Jacob, M.; Leipert, S.; Salmon, A.H.J.; Chappell, D. Degradation of the Endothelial Glycocalyx in Clinical Settings: Searching for the Sheddases. Br. J. Clin. Pharmacol. 2015, 80, 389-402. [CrossRef]

79. Tanaka, T.; Takabuchi, S.; Nishi, K.; Oda, S.; Wakamatsu, T.; Daijo, H.; Fukuda, K.; Hirota, K. The Intravenous Anesthetic Propofol Inhibits Lipopolysaccharide-Induced Hypoxia-Inducible Factor 1 Activation and Suppresses the Glucose Metabolism in Macrophages. J. Anesth. 2009, 24, 54-60. [CrossRef] [PubMed]

80. Reitsma, S.; Slaaf, D.W.; Vink, H.; van Zandvoort, M.A.M.J.; Oude Egbrink, M.G.A. The Endothelial Glycocalyx: Composition, Functions, and Visualization. Pflügers Arch. Eur. J. Physiol. 2007, 454, 345-359. [CrossRef] [PubMed] 
81. Alphonsus, C.S.; Rodseth, R.N. The Endothelial Glycocalyx: A Review of the Vascular Barrier. Anaesthesia 2014, 69, 777-784. [CrossRef] [PubMed]

82. Annecke, T.; Chappell, D.; Chen, C.; Jacob, M.; Welsch, U.; Sommerhoff, C.P.; Rehm, M.; Conzen, P.F.; Becker, B.F. Sevoflurane Preserves the Endothelial Glycocalyx against Ischaemia-Reperfusion Injury. Br. J. Anaesth. 2010, 104, 414-421. [CrossRef]

83. Chappell, D.; Heindl, B.; Jacob, M.; Annecke, T.; Chen, C.; Rehm, M.; Conzen, P.; Becker, B.F. Sevoflurane Reduces Leukocyte and Platelet Adhesion after Ischemia-Reperfusion by Protecting the Endothelial Glycocalyx. Anesthesiology 2011, 115, 483-491. [CrossRef] [PubMed]

84. Becker, B.F.; Chen, C.; Chappell, D.; Annecke, T.; Conzen, P.; Jacob, M.; Welsch, U.; Zwissler, B. Sevoflurane Mitigates Shedding of Hyaluronan from the Coronary Endothelium, Also during Ischemia/Reperfusion: An Ex Vivo Animal Study. Hypoxia 2016, 4 , 81-90. [CrossRef]

85. Annecke, T.; Rehm, M.; Bruegger, D.; Kubitz, J.C.; Kemming, G.I.; Stoekelhuber, M.; Becker, B.F.; Conzen, P.F. IschemiaReperfusion-Induced Unmeasured Anion Generation and Glycocalyx Shedding: Sevoflurane versus Propofol Anesthesia. J. Investig. Surg. 2012, 25, 162-168. [CrossRef]

86. Rosenberger, C. Expression of Hypoxia-Inducible Factor-1 and -2 in Hypoxic and Ischemic Rat Kidneys. J. Am. Soc. Nephrol. 2002, 13, 1721-1732. [CrossRef] [PubMed]

87. Wiesener, M.S.; Jürgensen, J.S.; Rosenberger, C.; Scholze, C.; Hörstrup, J.H.; Warnecke, C.; Mandriota, S.; Bechmann, I.; Frei, U.A.; Pugh, C.W.; et al. Widespread, Hypoxia-inducible Expression of HIF-2 $\alpha$ in Distinct Cell Populations of Different Organs. Faseb J. 2002, 17, 271-273. [CrossRef]

88. Eltzschig, H.K.; Carmeliet, P. Hypoxia and Inflammation. N. Engl. J. Med. 2011, 364, 656-665. [CrossRef]

89. Oda, T.; Ishimura, T.; Yokoyama, N.; Ogawa, S.; Miyake, H.; Fujisaw, M. Hypoxia-Inducible Factor-1 $\alpha$ Expression in Kidney Transplant Biopsy Specimens After Reperfusion Is Associated With Early Recovery of Graft Function After Cadaveric Kidney Transplantation. Transpl. Proc. 2017, 49, 68-72. [CrossRef]

90. Kojima, I.; Tanaka, T.; Inagi, R.; Kato, H.; Yamashita, T.; Sakiyama, A.; Ohneda, O.; Takeda, N.; Sata, M.; Miyata, T.; et al. Protective Role of Hypoxia-Inducible Factor-2 $\alpha$ against Ischemic Damage and Oxidative Stress in the Kidney. J. Am. Soc. Nephrol. 2007, 18, 1218-1226. [CrossRef]

91. Yang, L.; Xie, P.; Wu, J.; Yu, J.; Yu, T.; Wang, H.; Wang, J.; Xia, Z.; Zheng, H. Sevoflurane Postconditioning Improves Myocardial Mitochondrial Respiratory Function and Reduces Myocardial Ischemia-Reperfusion Injury by up-Regulating HIF-1. Am. J. Transl. Res. 2016, 8, 4415-4424. [PubMed]

92. Zheng, B.; Zhan, Q.; Chen, J.; Xu, H.; He, Z. Sevoflurane Pretreatment Enhance HIF-2 $\alpha$ Expression in Mice after Renal Ischemia/Reperfusion Injury. Int. J. Clin. Exp. Pathol. 2015, 8, 13114-13119.

93. Zhao, H.; Watts, H.R.; Chong, M.; Huang, H.; Tralau-Stewart, C.; Maxwell, P.H.; Maze, M.; George, A.J.T.; Ma, D. Xenon Treatment Protects Against Cold Ischemia Associated Delayed Graft Function and Prolongs Graft Survival in Rats. Am. J. Transpl. 2013, 13, 2006-2018. [CrossRef]

94. Ye, Z.; Guo, Q.; Xia, P.; Wang, N.; Wang, E.; Yuan, Y. Sevoflurane Postconditioning Involves an Up-Regulation of HIF-1 $\alpha$ and HO-1 Expression via PI3K/Akt Pathway in a Rat Model of Focal Cerebral Ischemia. Brain Res. 2012, 1463, 63-74. [CrossRef] [PubMed]

95. Chiari, P.C.; Bienengraeber, M.W.; Pagel, P.S.; Krolikowski, J.G.; Kersten, J.R.; Warltier, D.C. Isoflurane Protects against Myocardial Infarction during Early Reperfusion by Activation of Phosphatidylinositol-3-Kinase Signal Transduction: Evidence for AnestheticInduced Postconditioning in Rabbits. Anesthesiology 2005, 102, 102-109. [CrossRef] [PubMed]

96. Huang, H.; Benzonana, L.L.; Zhao, H.; Watts, H.R.; Perry, N.J.S.; Bevan, C.; Brown, R.; Ma, D. Prostate Cancer Cell Malignancy via Modulation of HIF-1 $\propto$ Pathway with Isoflurane and Propofol Alone and in Combination. Br. J. Cancer 2014, 111, 1338-1349. [CrossRef] [PubMed]

97. Yeh, C.-H.; Cho, W.; So, E.C.; Chu, C.-C.; Lin, M.-C.; Wang, J.-J.; Hsing, C.-H. Propofol Inhibits Lipopolysaccharide-Induced Lung Epithelial Cell Injury by Reducing Hypoxia-Inducible Factor-1 $\alpha$ Expression. Br. J. Anaesth. 2011, 106, 590-599. [CrossRef]

98. Lee, H.T.; Kim, M.; Kim, J.; Kim, N.; Emala, C.W. TGF-Beta1 Release by Volatile Anesthetics Mediates Protection against Renal Proximal Tubule Cell Necrosis. Am. J. Nephrol. 2007, 27, 416-424. [CrossRef] [PubMed]

99. Huynh, M.-L.N.; Fadok, V.A.; Henson, P.M. Phosphatidylserine-Dependent Ingestion of Apoptotic Cells Promotes TGF-Beta1 Secretion and the Resolution of Inflammation. J. Clin. Investig. 2002, 109, 41-50. [CrossRef] [PubMed]

100. Song, J.H.; Kim, M.; Park, S.W.; Chen, S.W.C.; Pitson, S.M.; Lee, H.T. Isoflurane via TGF-B1 Release Increases Caveolae Formation and Organizes Sphingosine Kinase Signaling in Renal Proximal Tubules. Am. J. Physiol. Ren. Physiol. 2010, 298, F1041-F1050. [CrossRef]

101. Xiao, Y.Q.; Malcolm, K.; Worthen, G.S.; Gardai, S.; Schiemann, W.P.; Fadok, V.A.; Bratton, D.L.; Henson, P.M. Cross-Talk between ERK and P38 MAPK Mediates Selective Suppression of Pro-Inflammatory Cytokines by Transforming Growth Factor- $\beta$. J. Biol. Chem. 2002, 277, 14884-14893. [CrossRef] [PubMed]

102. Hart, M.L.; Jacobi, B.; Schittenhelm, J.; Henn, M.; Eltzschig, H.K. Cutting Edge: A2B Adenosine Receptor Signaling Provides Potent Protection during Intestinal Ischemia/Reperfusion Injury. J. Immunol. 2009, 182, 3965-3968. [CrossRef] [PubMed]

103. Grenz, A.; Zhang, H.; Eckle, T.; Mittelbronn, M.; Wehrmann, M.; Köhle, C.; Kloor, D.; Thompson, L.F.; Osswald, H.; Eltzschig, H.K. Protective Role of Ecto-5'-Nucleotidase (CD73) in Renal Ischemia. J. Am. Soc. Nephrol. 2007, 18, 833-845. [CrossRef] [PubMed] 
104. Eckle, T.; Krahn, T.; Grenz, A.; Köhler, D.; Mittelbronn, M.; Ledent, C.; Jacobson, M.A.; Osswald, H.; Thompson, L.F.; Unertl, K.; et al. Cardioprotection by Ecto-5' - Nucleotidase (CD73) and A2BAdenosine Receptors. Circulation 2007, 115, 1581-1590. [CrossRef]

105. Kim, M.; Kim, M.; Park, S.W.; Pitson, S.M.; Lee, H.T. Isoflurane Protects Human Kidney Proximal Tubule Cells against Necrosis via Sphingosine Kinase and Sphingosine-1-Phosphate Generation. Am. J. Nephrol. 2010, 31, 353-362. [CrossRef]

106. Park, S.W.; Kim, M.; Kim, J.Y.; Brown, K.M.; Haase, V.H.; D’Agati, V.D.; Lee, H.T. Proximal Tubule Sphingosine Kinase-1 Has a Critical Role in A1 Adenosine Receptor-Mediated Renal Protection from Ischemia. Kidney Int. 2012, 82, 878-891. [CrossRef]

107. Kim, J.Y.; Kim, M.; Ham, A.; Brown, K.M.; Greene, R.W.; D'Agati, V.D.; Lee, H.T. IL-11 Is Required for A1Adenosine ReceptorMediated Protection against Ischemic AKI. J. Am. Soc. Nephrol. 2013, 24, 1558-1570. [CrossRef]

108. Zhou, Y.; Lekic, T.; Fathali, N.; Ostrowski, R.P.; Martin, R.D.; Tang, J.; Zhang, J.H. Isoflurane Posttreatment Reduces Neonatal Hypoxic-Ischemic Brain Injury in Rats by the Sphingosine-1-Phosphate/Phosphatidylinositol-3-Kinase/Akt Pathway. Stroke 2010, 41, 1521-1527. [CrossRef] [PubMed]

109. Olivera, A.; Kohama, T.; Edsall, L.; Nava, V.; Cuvillier, O.; Poulton, S.; Spiegel, S. Sphingosine Kinase Expression Increases Intracellular Sphingosine-1-Phosphate and Promotes Cell Growth and Survival. J. Cell Biol. 1999, 147, 545-558. [CrossRef] [PubMed]

110. Spiegel, S.; Milstien, S. Sphingosine-1-Phosphate: An Enigmatic Signalling Lipid. Nat. Rev. Mol. Cell Biol. 2003, 4, 397-407. [CrossRef]

111. Davaille, J.; Li, L.; Mallat, A.; Lotersztajn, S. Sphingosine 1-Phosphate Triggers Both Apoptotic and Survival Signals for Human Hepatic Myofibroblasts. J. Biol. Chem. 2002, 277, 37323-37330. [CrossRef] [PubMed]

112. Bakar, A.M.; Park, S.W.; Kim, M.; Lee, H.T. Isoflurane Protects Against Human Endothelial Cell Apoptosis by Inducing Sphingosine Kinase-1 via ERK MAPK. Int. J. Mol. Sci. 2012, 13, 977-993. [CrossRef] [PubMed]

113. Somers, S.J.; Frias, M.; Lacerda, L.; Opie, L.H.; Lecour, S. Interplay Between SAFE and RISK Pathways in Sphingosine-1-PhosphateInduced Cardioprotection. Cardiovasc. Drugs Ther. 2012, 26, 227-237. [CrossRef]

114. Kim, M.; Kim, M.; Kim, N.; D’Agati, V.D.; Emala, C.W.; Lee, H.T. Isoflurane Mediates Protection from Renal Ischemia-Reperfusion Injury via Sphingosine Kinase and Sphingosine-1-Phosphate-Dependent Pathways. Am. J. Physiol. Ren. Physiol. 2007, 293, F1827-F1835. [CrossRef]

115. Bajwa, A.; Jo, S.-K.; Ye, H.; Huang, L.; Dondeti, K.R.; Rosin, D.L.; Haase, V.H.; Macdonald, T.L.; Lynch, K.R.; Okusa, M.D. Activation of Sphingosine-1-Phosphate 1 Receptor in the Proximal Tubule Protects Against Ischemia-Reperfusion Injury. J. Am. Soc. Nephrol. 2010, 21, 955-965. [CrossRef]

116. Fuller, T.F.; Hoff, U.; Kong, L.; Naether, M.; Wagner, P.; Nieminen-Kelhä, M.; Nolting, J.; Luft, F.C.; Hegner, B.; Dragun, D. Cytoprotective Actions of FTY720 Modulate Severe Preservation Reperfusion Injury in RatRenal Transplants. Transplantation 2010, 89, 402-408. [CrossRef]

117. Damman, J.; Seelen, M.A.; Moers, C.; Daha, M.R.; Rahmel, A.; Leuvenink, H.G.; Paul, A.; Pirenne, J.; Ploeg, R.J. Systemic Complement Activation in Deceased Donors Is Associated With Acute Rejection After Renal Transplantation in the Recipient. Transplantation 2011, 92, 163-169. [CrossRef] [PubMed]

118. Damman, J.; Daha, M.R.; van Son, W.J.; Leuvenink, H.G.; Ploeg, R.J.; Seelen, M.A. Crosstalk between Complement and Toll-like Receptor Activation in Relation to Donor Brain Death and Renal Ischemia-Reperfusion Injury. Am. J. Transpl. 2011, 11, 660-669. [CrossRef]

119. Land, W.; Schneeberger, H.; Schleibner, S.; Illner, W.-D.; Abendroth, D.; Rutili, G.; Arfors, K.E.; Messmer, K. The Beneficial Effect of Human Recombinant Superoxide Dismutase On Acute And Chronic Rejection Events In Recipients Of Cadaveric Renal Transplants. Transplantation 1994, 57, 211-217. [CrossRef]

120. Matzinger, P. Tolerance, Danger, and the Extended Family. Annu. Rev. Immunol. 1994, 12, 991-1045. [CrossRef] [PubMed]

121. Halloran, P.; Melk, A.; Barth, C. Rethinking Chronic Allograft Nephropathy: The Concept of Accelerated Senescence. J. Am. Soc. Nephrol. 1999, 10, 167-181.

122. Halloran, P.F.; Reeve, J.P.; Pereira, A.B.; Hidalgo, L.G.; Famulski, K.S. Antibody-Mediated Rejection, T Cell-Mediated Rejection, and the Injury-Repair Response: New Insights from the Genome Canada Studies of Kidney Transplant Biopsies. Kidney Int. 2014, 85, 258-264. [CrossRef] [PubMed]

123. Jang, H.R.; Rabb, H. The Innate Immune Response in Ischemic Acute Kidney Injury. Clin. Immunol. 2009, 130, 41-50. [CrossRef] [PubMed]

124. Fröhlich, D.; Rothe, G.; Schwall, B.; Schmid, P.; Schmitz, G.; Taeger, K.; Hobbhahn, J. Effects of Volatile Anaesthetics on Human Neutrophil Oxidative Response to the Bacterial Peptide FMLP. Br. J. Anaesth. 1997, 78, 718-723. [CrossRef]

125. Mobert, J.; Zahler, S.; Becker, B.F.; Conzen, P.F. Inhibition of Neutrophil Activation by Volatile Anesthetics Decreases Adhesion to Cultured Human Endothelial Cells. Anesthesiology 1999, 90, 1372-1381. [CrossRef] [PubMed]

126. Kong, H.Y.; Zhu, S.M.; Wang, L.Q.; He, Y.; Xie, H.Y.; Zheng, S.S. Sevoflurane Protects against Acute Kidney Injury in a Small-Size Liver Transplantation Model. Am. J. Nephrol. 2010, 32, 347-355. [CrossRef] [PubMed]

127. Abbas, A.K.; Lichtman, A.H.; Pillai, S.; Baker, A.; Baker, D.L. Cellular and Molecular Immunology, 8th ed.; Elsevier Saunders: Philadelphia, PA, USA, 2014.

128. Jo, S.-K.; Sung, S.-A.; Cho, W.-Y.; Go, K.-J.; Kim, H.-K. Macrophages Contribute to the Initiation of Ischaemic Acute Renal Failure in Rats. Nephrol. Dial. Transpl. 2006, 21, 1231-1239. [CrossRef] 
129. Cho, E.J.; Yoon, J.H.; Hong, S.J.; Lee, S.H.; Sim, S.B. The Effects of Sevoflurane on Systemic and Pulmonary Inflammatory Responses after Cardiopulmonary Bypass. J. Cardiothorac. Vasc. Anesth. 2009, 23, 639-645. [CrossRef] [PubMed]

130. Flondor, M.; Hofstetter, C.; Boost, K.A.; Betz, C.; Homann, M.; Zwissler, B. Isoflurane Inhalation after Induction of Endotoxemia in Rats Attenuates the Systemic Cytokine Response. Eur. Surg. Res. 2007, 40, 1-6. [CrossRef] [PubMed]

131. Tschaikowsky, K.; Ritter, J.; Schröppel, K.; Kühn, M. Volatile Anesthetics Differentially Affect Immunostimulated Expression of Inducible Nitric Oxide Synthase. Anesthesiology 2000, 92, 1093-1102. [CrossRef]

132. Huen, S.C.; Cantley, L.G. Macrophages in Renal Injury and Repair. Annu. Rev. Physiol. 2017, 79, 449-469. [CrossRef]

133. Mark, L.A.; Robinson, A.V.; Schulak, J.A. Inhibition of Nitric Oxide Synthase Reduces Renal Ischemia/Reperfusion Injury. J. Surg. Res. 2005, 129, 236-241. [CrossRef] [PubMed]

134. Chatterjee, P.K.; Patel, N.S.A.; Kvale, E.O.; Cuzzocrea, S.; Brown, P.A.J.; Stewart, K.N.; Mota-Filipe, H.; Thiemermann, C. Inhibition of Inducible Nitric Oxide Synthase Reduces Renal Ischemia/Reperfusion Injury. Kidney Int. 2002, 61, 862-871. [CrossRef] [PubMed]

135. Toda, N.; Toda, H.; Hatano, Y. Anesthetic Modulation of Immune Reactions Mediated by Nitric Oxide. J. Anesth. 2008, 22, 155-162. [CrossRef]

136. Zha, H.; Matsunami, E.; Blazon-Brown, N.; Koutsogiannaki, S.; Hou, L.; Bu, W.; Babazada, H.; Odegard, K.C.; Liu, R.; Eckenhoff, R.G.; et al. Volatile Anesthetics Affect Macrophage Phagocytosis. PLoS ONE 2019, 14, e0216163. [CrossRef] [PubMed]

137. Angka, L.; Khan, S.; Kilgour, M.; Xu, R.; Kennedy, M.; Auer, R. Dysfunctional Natural Killer Cells in the Aftermath of Cancer Surgery. Int. J. Mol. Sci. 2017, 18, 1787. [CrossRef]

138. Zhang, Z.-X.; Wang, S.; Huang, X.; Min, W.-P.; Sun, H.; Liu, W.; Garcia, B.; Jevnikar, A.M. NK Cells Induce Apoptosis in Tubular Epithelial Cells and Contribute to Renal Ischemia-Reperfusion Injury. J. Immunol. 2008, 181, 7489-7498. [CrossRef]

139. Zhang, J.; Han, C.; Dai, H.; Hou, J.; Dong, Y.; Cui, X.; Xu, L.; Zhang, M.; Xia, Q. Hypoxia-Inducible Factor-2 $\alpha$ Limits Natural Killer T Cell Cytotoxicity in Renal Ischemia/Reperfusion Injury. J. Am. Soc. Nephrol. 2015, 27, 92-106. [CrossRef] [PubMed]

140. Li, L.; Huang, L.; Sung, S.J.; Lobo, P.I.; Brown, M.G.; Gregg, R.K.; Engelhard, V.H.; Okusa, M.D. NKT Cell Activation Mediates Neutrophil IFN- $\gamma$ Production and Renal Ischemia-Reperfusion Injury. J. Immunol. 2007, 178, 5899-5911. [CrossRef]

141. Welden, B.; Gates, G.; Mallari, R.; Garrett, N. Effects of Anesthetics and Analgesics on Natural Killer Cell Activity. AANA J 2009, 77, 287-292.

142. Melamed, R.; Bar-Yosef, S.; Shakhar, G.; Shakhar, K.; Ben-Eliyahu, S. Suppression of Natural Killer Cell Activity and Promotion of Tumor Metastasis by Ketamine, Thiopental, and Halothane, but Not by Propofol: Mediating Mechanisms and Prophylactic Measures. Anesth. Analg. 2003, 1331-1339. [CrossRef]

143. Wada, H.; Seki, S.; Takahashi, T.; Kawarabayashi, N.; Higuchi, H.; Habu, Y.; Sugahara, S.; Kazama, T. Combined Spinal and General Anesthesia Attenuates Liver Metastasis by Preserving Th1/Th2 Cytokine Balance. Anesthesiology 2007, 106, 499-506. [CrossRef]

144. Markovic, S.N.; Knight, P.R.; Murasko, D.M. Inhibition of Interferon Stimulation of Natural Killer Cell Activity in Mice Anesthetized with Halothane or Isoflurane. Anesthesiology 1993, 78, 700-706. [CrossRef] [PubMed]

145. Sessler, D.I. Does Regional Analgesia Reduce the Risk of Cancer Recurrence? A Hypothesis. Eur. J. Cancer Prev. 2008, 17, $269-272$. [CrossRef]

146. Brand, J.-M.; Kirchner, H.; Poppe, C.; Schmucker, P. The Effects of General Anesthesia on Human Peripheral Immune Cell Distribution and Cytokine Production. Clin. Immunol. Immunopathol. 1997, 83, 190-194. [CrossRef]

147. Ai, L.; Wang, H. Effects of Propofol and Sevoflurane on Tumor Killing Activity of Peripheral Blood Natural Killer Cells in Patients with Gastric Cancer. J. Int. Med. Res. 2020, 48, 030006052090486. [CrossRef] [PubMed]

148. Ysebaert, D.K.; De Greef, K.E.; De Beuf, A.; Van Rompay, A.N.R.; Vercauteren, S.; Persy, V.P.; De Broe, M.E. T Cells as Mediators in Renal Ischemia/Reperfusion Injury. Kidney Int. 2004, 66, 491-496. [CrossRef]

149. de Perrot, M.; Young, K.; Imai, Y.; Liu, M.; Waddell, T.K.; Fischer, S.; Zhang, L.; Keshavjee, S. Recipient T Cells Mediate Reperfusion Injury after Lung Transplantation in the Rat. J. Immunol. 2003, 171, 4995-5002. [CrossRef]

150. Fiorina, P.; Ansari, M.J.; Jurewicz, M.; Barry, M.; Ricchiuti, V.; Smith, R.N.; Shea, S.; Means, T.K.; Auchincloss, H.; Luster, A.D.; et al. Role of CXC Chemokine Receptor 3 Pathway in Renal Ischemic Injury. J. Am. Soc. Nephrol. 2006, 17, 716-723. [CrossRef] [PubMed]

151. Rabb, H. The T Cell as a Bridge between Innate and Adaptive Immune Systems: Implications for the Kidney. Kidney Int. 2002, 61, 1935-1946. [CrossRef] [PubMed]

152. Rabb, H.; Daniels, F.; O’Donnell, M.; Haq, M.; Saba, S.R.; Keane, W.; Tang, W.W. Pathophysiological Role of T Lymphocytes in Renal Ischemia-Reperfusion Injury in Mice. Am. J. Physiol. Ren. Physiol. 2000, 279, F525-F531. [CrossRef]

153. Burne, M.J.; Daniels, F.; El Ghandour, A.; Mauiyyedi, S.; Colvin, R.B.; O’Donnell, M.P.; Rabb, H. Identification of the CD4+ T Cell as a Major Pathogenic Factor in Ischemic Acute Renal Failure. J. Clin. Investig. 2001, 108, 1283-1290. [CrossRef] [PubMed]

154. Day, Y.-J.; Huang, L.; Ye, H.; Li, L.; Linden, J.; Okusa, M.D. Renal Ischemia-Reperfusion Injury and Adenosine 2A ReceptorMediated Tissue Protection: The Role of CD4+T Cells and IFN- $\gamma$. J. Immunol. 2006, 176, 3108-3114. [CrossRef] [PubMed]

155. Ko, G.J.; Linfert, D.; Jang, H.R.; Higbee, E.; Watkins, T.; Cheadle, C.; Liu, M.; Racusen, L.; Grigoryev, D.N.; Rabb, H. Transcriptional Analysis of Infiltrating T Cells in Kidney Ischemia-Reperfusion Injury Reveals a Pathophysiological Role for CCR5. Am. J. Physiol. Ren. Physiol. 2012, 302, F762-F773. [CrossRef] 
156. Guo, L.; Lee, H.H.; Noriega, M.D.L.M.; Paust, H.J.; Zahner, G.; Thaiss, F. Lymphocyte-Specific Deletion of IKK2 or NEMO Mediates an Increase in Intrarenal Th17 Cells and Accelerates Renal Damage in an Ischemia-Reperfusion Injury Mouse Model. Am. J. Physiol. Ren. Physiol. 2016, 311, F1005-F1014. [CrossRef]

157. Zhang, M.-Z.; Wang, X.; Wang, Y.; Niu, A.; Wang, S.; Zou, C.; Harris, R.C. IL-4/IL-13-Mediated Polarization of Renal Macrophages/Dendritic Cells to an M2a Phenotype Is Essential for Recovery from Acute Kidney Injury. Kidney Int. 2017, 91, 375-386. [CrossRef]

158. Ren, X.F.; Li, W.Z.; Meng, F.Y.; Lin, C.F. Differential Effects of Propofol and Isoflurane on the Activation of T-Helper Cells in Lung Cancer Patients. Anaesthesia 2010, 65, 478-482. [CrossRef]

159. Inada, T.; Yamanouchi, Y.; Jomura, S.; Sakamoto, S.; Takahashi, M.; Kambara, T.; Shingu, K. Effect of Propofol and Isoflurane Anaesthesia on the Immune Response to Surgery. Anaesthesia 2004, 59, 954-959. [CrossRef] [PubMed]

160. Woo, J.H.; Baik, H.J.; Kim, C.H.; Chung, R.K.; Kim, D.Y.; Lee, G.Y.; Chun, E.H. Effect of Propofol and Desflurane on Immune Cell Populations in Breast Cancer Patients: A Randomized Trial. J. Korean Med Sci. 2015, 30, 1503. [CrossRef]

161. Wood, K.J.; Sakaguchi, S. Regulatory T Cells in Transplantation Tolerance. Nat. Rev. Immunol. 2003, 3, 199-210. [CrossRef]

162. Ferrer, I.R.; Hester, J.; Bushell, A.; Wood, K.J. Induction of Transplantation Tolerance through Regulatory Cells: From Mice to Men. Immunol. Rev. 2014, 258, 102-116. [CrossRef]

163. Jun, C.; Qingshu, L.; Ke, W.; Ping, L.; Jun, D.; Jie, L.; Su, M. Protective Effect of CXCR3+CD4+CD25+Foxp3+Regulatory T Cells in Renal Ischemia-Reperfusion Injury. Mediat. Inflamm. 2015, 2015, 360973. [CrossRef] [PubMed]

164. Oh, C.-S.; Lee, J.; Yoon, T.-G.; Seo, E.-H.; Park, H.-J.; Piao, L.; Lee, S.-H.; Kim, S.-H. Effect of Equipotent Doses of Propofol versus Sevoflurane Anesthesia on Regulatory T Cells after Breast Cancer Surgery. Anesthesiology 2018, 129, 921-931. [CrossRef]

165. Chutipongtanate, A.; Prukviwat, S.; Pongsakul, N.; Srisala, S.; Kamanee, N.; Arpornsujaritkun, N.; Gesprasert, G.; Apiwattanakul, N.; Hongeng, S.; Ittichaikulthol, W.; et al. Effects of Desflurane and Sevoflurane Anesthesia on Regulatory T Cells in Patients Undergoing Living Donor Kidney Transplantation: A Randomized Intervention Trial. BMC Anesthesiol. 2020, 20. [CrossRef]

166. Loop, T.; Dovi-Akue, D.; Frick, M.; Roesslein, M.; Egger, L.; Humar, M.; Hoetzel, A.; Schmidt, R.; Borner, C.; Pahl, H.L.; et al. Volatile Anesthetics Induce Caspase-Dependent, Mitochondria-Mediated Apoptosis in Human T Lymphocytes In Vitro. Anesthesiology 2005, 102, 1147-1157. [CrossRef] [PubMed]

167. Matsuoka, H.; Kurosawa, S.; Horinouchi, T.; Kato, M.; Hashimoto, Y. Inhalation Anesthetics Induce Apoptosis in Normal Peripheral Lymphocytes In Vitro. Anesthesiology 2001, 95, 1467-1472. [CrossRef]

168. Jang, H.R.; Gandolfo, M.T.; Ko, G.J.; Satpute, S.R.; Racusen, L.; Rabb, H. B Cells Limit Repair after Ischemic Acute Kidney Injury. J. Am. Soc. Nephrol. 2010, 21, 654-665. [CrossRef] [PubMed]

169. Martins, H.L.; Silva, C.; Martini, D.; Noronha, I.L. Detection of B Lymphocytes (CD20+) in Renal Allograft Biopsy Specimens. Transpl. Proc. 2007, 39, 432-434. [CrossRef] [PubMed]

170. Puig, N.R.; Ferrero, P.; Bay, M.L.; Hidalgo, G.; Valenti, J.; Amerio, N.; Elena, G. Effects of Sevoflurane General Anesthesia: Immunological Studies in Mice. Int. Immunopharmacol. 2002, 2, 95-104. [CrossRef]

171. Liu, S.; Gu, X.; Zhu, L.; Wu, G.; Zhou, H.; Song, Y.; Wu, C. Effects of Propofol and Sevoflurane on Perioperative Immune Response in Patients Undergoing Laparoscopic Radical Hysterectomy for Cervical Cancer. Medicine 2016, 95, e5479. [CrossRef] [PubMed]

172. Yuki, K.; Astrof, N.S.; Bracken, C.; Yoo, R.; Silkworth, W.; Soriano, S.G.; Shimaoka, M. The Volatile Anesthetic Isoflurane Perturbs Conformational Activation of Integrin LFA-1 by Binding to the Allosteric Regulatory Cavity. FASEB J. 2008, 22, $4109-4116$. [CrossRef] [PubMed]

173. Yuki, K.; Astrof, N.S.; Bracken, C.; Soriano, S.G.; Shimaoka, M. Sevoflurane Binds and Allosterically Blocks Integrin Lymphocyte Function-Associated Antigen-1. Anesthesiology 2010, 113, 600-609. [CrossRef]

174. Yuki, K.; Bu, W.; Xi, J.; Sen, M.; Shimaoka, M.; Eckenhoff, R.G. Isoflurane Binds and Stabilizes a Closed Conformation of the Leukocyte Function-associated Antigen-1. FASEB J. 2012, 26, 4408-4417. [CrossRef] [PubMed]

175. Springer, T.A. Traffic Signals for Lymphocyte Recirculation and Leukocyte Emigration: The Multistep Paradigm. Cell 1994, 76, 301-314. [CrossRef]

176. Thomas, L.M.; Peterson, M.E.; Long, E.O. Cutting Edge: NK Cell Licensing Modulates Adhesion to Target Cells. J. Immunol. 2013, 191, 3981-3985. [CrossRef] [PubMed]

177. Barber, D.F.; Faure, M.; Long, E.O. LFA-1 Contributes an Early Signal for NK Cell Cytotoxicity. J. Immunol. 2004, 173, 3653-3659. [CrossRef] [PubMed]

178. Nicolls, M.R.; Coulombe, M.; Yang, H.; Bolwerk, A.; Gill, R.G. Anti-LFA-1 Therapy Induces Long-Term Islet Allograft Acceptance in the Absence of IFN- $\gamma$ or IL-4. J. Immunol. 2000, 164, 3627-3634. [CrossRef]

179. Arefanian, H.; Tredget, E.B.; Rajotte, R.V.; Korbutt, G.S.; Gill, R.G.; Rayat, G.R. Combination of Anti-CD4 with Anti-LFA-1 and Anti-CD154 Monoclonal Antibodies Promotes Long-Term Survival and Function of Neonatal Porcine Islet Xenografts in Spontaneously Diabetic NOD Mice. Cell Transpl. 2007, 16, 787-798. [CrossRef]

180. Badell, I.R.; Russell, M.C.; Thompson, P.W.; Turner, A.P.; Weaver, T.A.; Robertson, J.M.; Avila, J.G.; Cano, J.A.; Johnson, B.E.; Song, M.; et al. LFA-1-Specific Therapy Prolongs Allograft Survival in Rhesus Macaques. J. Clin. Investig. 2010, 120, $4520-4531$. [CrossRef] [PubMed]

181. Vincenti, F.; Mendez, R.; Pescovitz, M.; Rajagopalan, P.R.; Wilkinson, A.H.; Butt, K.; Laskow, D.; Slakey, D.P.; Lorber, M.I.; Garg, J.P.; et al. A Phase I/II Randomized Open-Label Multicenter Trial of Efalizumab, a Humanized Anti-CD11a, Anti-LFA-1 in Renal Transplantation. Am. J. Transplant. 2007, 7, 1770-1777. [CrossRef] 
182. Research, C. For D. E. and. Efalizumab (Marketed as Raptiva) Information; FDA: 2019. Available online: https://www.fda.gov/ drugs/postmarket-drug-safety-information-patients-and-providers/efalizumab-marketed-raptiva-information (accessed on 24 February 2021).

183. Yuki, K.; Bu, W.; Xi, J.; Shimaoka, M.; Eckenhoff, R. Propofol Shares the Binding Site with Isoflurane and Sevoflurane on Leukocyte Function-Associated Antigen-1. Anesth. Analg. 2013, 117, 803-811. [CrossRef]

184. Perez-Protto, S.; Nazemian, R.; Matta, M.; Patel, P.; Wagner, K.J.; Latifi, S.Q.; Lebovitz, D.J.; Reynolds, J.D. The effect of inhalational anaesthesia during deceased donor organ procurement on post-transplantation graft survival. Anaesth. Intensive Care 2018, 46, 178-184. [CrossRef]

185. Lee, J.H.; Joo, D.J.; Kim, J.M.; Park, J.H.; Kim, Y.S.; Koo, B.N. Preconditioning effects of the anesthetic administered to the donor on grafted kidney function in living donor kidney transplantation recipients. Minerva Anestesiol. 2013, 79, 504-514. [PubMed]

186. Nieuwenhuijs-Moeke, G.J.; Nieuwenhuijs, V.B.; Seelen, M.A.J.; Berger, S.P.; van den Heuvel, M.C.; Burgerhof, J.G.M.; Ottens, P.J.; Ploeg, R.J.; Leuvenink, H.G.D.; Struys, M.M.R.F. Propofol-Based Anaesthesia versus Sevoflurane-Based Anaesthesia for Living Donor Kidney Transplantation: Results of the VAPOR-1 Randomized Controlled Trial. Br. J. Anaesth. 2017, 118, 720-732. [CrossRef]

187. Yang, L.; Brooks, C.R.; Xiao, S.; Sabbisetti, V.; Yeung, M.Y.; Hsiao, L.-L.; Ichimura, T.; Kuchroo, V.; Bonventre, J.V. KIM-1-Mediated Phagocytosis Reduces Acute Injury to the Kidney. J. Clin. Investig. 2015, 125, 1620-1636. [CrossRef] [PubMed]

188. Ichimura, T.; Brooks, C.R.; Bonventre, J.V. Kim-1/Tim-1 and Immune Cells: Shifting Sands. Kidney Int. $2012,81,809-811$. [CrossRef] [PubMed]

189. Park, J.H.; Lee, J.H.; Joo, D.J.; Song, K.J.; Kim, Y.S.; Koo, B.N. Effect of sevoflurane on grafted kidney function in renal transplantation. Korean J. Anesth. 2012, 62, 529-535. [CrossRef] [PubMed]

190. Savran Karadeniz, M.; Senturk Ciftci, H.; Tefik, T.; Oktar, T.; Nane, I.; Turkmen, A.; Oguz, F.; Tugrul, K.M. Effects of Different Volatile Anesthetics on Cytokine and Chemokine Production After Ischemia-Reperfusion Injury in Patients Undergoing LivingDonor Kidney Transplant. Exp. Clin. Transplant. 2019, 17 (Suppl. 1), 68-74. [CrossRef] [PubMed] 